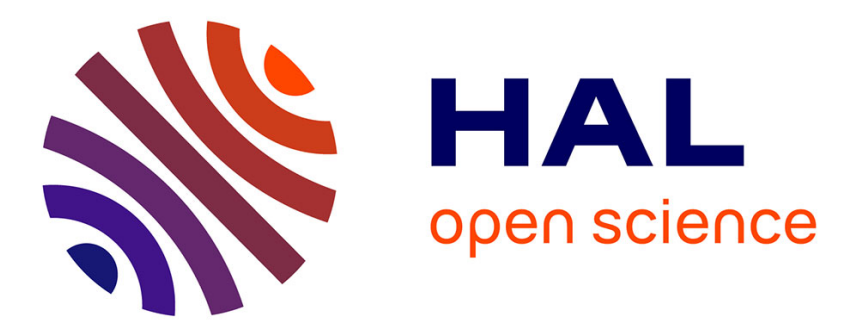

\title{
Subjective well-being and social comparison : a comparative study on rural Thailand and Vietnam
}

Thi Kim Cuong Pham, Phu Nguyen-Van, Thanh Tam Nguyen-Huu, Thi Anh-Dao Tran, Noukignon Kone

\section{- To cite this version:}

Thi Kim Cuong Pham, Phu Nguyen-Van, Thanh Tam Nguyen-Huu, Thi Anh-Dao Tran, Noukignon Kone. Subjective well-being and social comparison: a comparative study on rural Thailand and Vietnam. Revue d'Economie Politique, 2019, 129 (6), pp.993-1029. 10.3917/redp.296.0993 . hal02456599

HAL Id: hal-02456599

https://hal-normandie-univ.archives-ouvertes.fr/hal-02456599

Submitted on 9 Sep 2021

HAL is a multi-disciplinary open access archive for the deposit and dissemination of scientific research documents, whether they are published or not. The documents may come from teaching and research institutions in France or abroad, or from public or private research centers.
L'archive ouverte pluridisciplinaire HAL, est destinée au dépôt et à la diffusion de documents scientifiques de niveau recherche, publiés ou non, émanant des établissements d'enseignement et de recherche français ou étrangers, des laboratoires publics ou privés. 


\title{
Subjective well-being and social comparison: A comparative study on rural Thailand and Vietnam*
}

\author{
Thi Kim Cuong Pham ${ }^{a \#} \quad$ Phu Nguyen-Van ${ }^{a, b} \quad$ Thanh-Tam Nguyen-Huu ${ }^{c}$ \\ Thi Anh-Dao $\operatorname{Tran}^{d}$ and Kone Noukignon ${ }^{d}$ \\ ${ }^{a}$ Université de Strasbourg, Université de Lorraine, CNRS, BETA \\ ${ }^{b}$ TIMAS, Vietnam, ${ }^{c}$ EM Normandie Business School, Métis Lab \\ ${ }^{d}$ CREAM, Université de Rouen
}

\begin{abstract}
This paper analyzes the determinants of the households' welfare perception using the data from surveys on rural households in Thailand and Vietnam. Welfare perception corresponds to the households' subjective assessment of their general situations. We focus on the social comparison and take into account relative poverty, harsh living conditions, economic and natural risks as well as the households' degree of risk acceptance. Our study shows that households, in both countries, are sensitive to income and relative poverty, but only Thai households appear to care about social comparison regarding their wealth. In particular, this comparison is asymmetric. Natural risks as well as households' attitude to risks affect households' well-being differently in the two countries, while we observe a similarity in the impact of economic shocks.

Key words: Economic risks, natural risks, rural area, social comparison; subjective well-being JEL classification: I31; O12; Q56
\end{abstract}

\section{Bien-être subjectif et comparaison sociale: une étude comparative entre les zones rurales de la Thailand et du Vietnam}

\section{Résumé}

Cet article analyse les déterminants du bien-être subjectif des ménages en utilisant une base de données d'enquêtes auprès des ménages habitant dans les zones rurales en Thailand et Vietnam. Le bien-être subjectif des ménages correspond à leur évaluation subjective de la situation générale au moment présent comparé au passé. Nous mettons l'accent sur la comparaison sociale en prenant en compte la pauvreté relative, les conditions de vie, les

\footnotetext{
* We hereby acknowledge the financial support of the RFCC (under the IBCCS grant). We are grateful to Agnès Bénassy-Quéré (guest editor of this issue), and the two anonymous reviewers for their very helpful comments. We also thank François Gardes and the participants at the 2018 AFSE Meeting (Paris), $4^{\text {th }}$ annual conference of the FAERE (Nancy), $2^{\text {nd }}$ Sustainability Workshop (Rouen) and LAMETA seminar for their remarks and suggestions. All remaining errors are our own.

\# Corresponding author: Thi Kim Cuong Pham, BETA, 61 avenue de la Forêt Noire, F-67000, Strasbourg Cedex, France; Phone : +33 (0)3 68852077 ; E-mail : kim.pham@unistra.fr.
} 
risques naturels ainsi que l'attitude des ménages face aux risques. Notre étude montre un effet significatif du revenu et de la pauvreté relative. Seuls les ménages Thaïlandais sont concernés par la comparaison en termes de richesse, qui est asymétrique. Les effets des risques naturels ainsi que ceux de l'attitude des ménages face aux risques sont différents entre deux pays, alors que ceux des risques économiques sur le bien-être subjectif sont plutôt similaires.

Mots clés: Risques économiques, risques naturels, zone rurale ; comparaison sociale; bienêtre subjectif 


\section{Introduction}

While standard economic theory assumes that individual utility is derived from absolute level of consumption or income, numerous empirical and experimental investigations have attempted to shed light on the aspect of relative standing (Luttmer, 2005, Alpizar et al. 2005, Carlsson et al. 2007, Clark et al. 2008, Fafchamps and Shilpi, 2008, etc.). This finding corroborates the idea of a social comparison already present in The Theory of Moral Sentiment (Smith, 1759) and more recently in The Social Limits to Growth (Hirsch, 1976). According to this idea, people derive satisfaction not only from their absolute position in terms of material conditions (consumption, income) but also from their relative position compared to their peers. Individuals have a tendency to compare their position to a reference point. This comparison behavior may be motivated by the desire to acquire social status, which induces social esteem, respect and admiration for individuals. Empirical investigations also show that relative income may matter differently according to the group of individuals. In particular, the rich might care more about their relative wealth than the poor (Ravallion and Lokshin, 2010, Ferrer-i-Carbonell, 2005).

Overall, we can observe that papers in this body of literature mainly focus on socioeconomic aspects and ignore issues of environmental quality or natural disasters. In the case of developing countries, households' living conditions are significantly affected by natural disasters and environmental vulnerability. Rural and poor households in particular are vulnerable to environmental shocks, and natural disasters (storms, floods and droughts) have a negative effect on income and expenditure in rural households (Nguyen et al. 2013, Kurosaki 2014, Arouri et al. 2015).

This paper fits into the literature of subjective well-being using the data from surveys on rural households in Vietnam and Thailand. It focuses on the effects of economic and environmental risks as well as on relative standing. First, we provide a test for relative standing with special attention to the asymmetric comparison hypothesis. Second, for the case of developing countries such as Vietnam and Thailand, this paper examines some characteristics of poor rural areas such as environmental and economic risks, vulnerability and harsh living conditions. Vulnerability encompasses not only the households' economic circumstances but also their situation in relation to the natural and geographical environment. Finally, we also analyze the nexus between households' welfare perception and selfassessment of general risk attitude. Welfare perception corresponds to the households' subjective assessment of their general situation. A households' attitude towards risk corresponds to their readiness in the event of economic and environmental risks.

Our study shows a significant effect of income on households' subjective well-being for two countries. Moreover, households are sensitive to relative poverty, i.e. earning an income lower than the village average makes households feel worse off than the previous year or the 5 previous years. However, we observe a divergence between the two countries in terms of social comparison, natural or economic shocks, and risk attitude. Only Thai households appear to care about social comparison regarding their wealth. They are asked to estimate if their wealth is better than the average of their village and of their country. Results 
show that Thai households feel happier compared to the past, when estimating that their wealth is better than the national average. This means that people do not compare themselves to their peers in the same village, but rather to others at national level. Given that this data concerns 3 poor and rural provinces in Thailand, this result may be interpreted as an upward comparison, and the national level with which people compare their wealth may be considered as a strong reference. Our results also show that natural risks (drought, flooding, heavy ice rain) affect households' well-being differently in the two countries, while we observe a similarity in the impact of economic shocks (pests or livestock disease). Concerning the effect of risk attitude, our results for Vietnam indicate that those who are more ready to accept risks feel better off in the present compared to the previous or the 5 previous years.

The present study contributes to the subjective well-being literature in the following ways. First, while the literature on this topic only focuses on the socio-economic aspect, we also consider environmental vulnerability and risk attitude. However, taking such factors into account is of great importance, particularly in the case of developing countries. On the one hand, poor households are likely to be more vulnerable in terms of natural shocks. On the other hand, with regard to subjective well-being, it seems that those with high risk acceptance are less affected by either natural or economic shocks than their risk avoidance counterparts. As for the empirical methodology, we carefully controlled for the endogeneity bias linked to some important explanatory variables (resulting from a reverse causality or measurement errors). Second, the comparison between Vietnamese and Thai households is also interesting since, to the best of our knowledge, this has not previously been studied in the literature. Third, findings derived from an analysis of subjective well-being and its determinants can have important policy implications, in particular for developing countries where income inequality is high compared to developed countries. If only absolute income matters, public policy should focus on reducing absolute poverty. If relative poverty affects individuals' wellbeing, policy-makers should pay attention to reducing poverty and inequality in order to improve the population's happiness. Moreover, the findings concerning the effects of natural disasters give some insights into environmental policies in both countries, in particular in terms of preventive policies.

The remainder of the paper is organized as follows: Section 2 provides a survey on subjective well-being focusing on low income countries. Section 3 presents the data and descriptive statistics. The econometric model and estimation results are presented in Sections 4 and 5 respectively. Section 6 concludes.

\section{Subjective well-being and social comparison}

Most studies on subjective well-being underscore a phenomenon of relative standing, contrary to the absolute utility hypothesis which is usually postulated in standard economic modelling. Relative standing effects differ between developed and developing countries, as well as between rich and poor individuals in a same country. In the case of developed countries, there is a consensus that a reference level exerts a negative effect on an individual's subjective well-being or life satisfaction, which is considered as a proxy of individual utility (McBride, 2001, Frijters et al., 2004, Luttmer, 2005, Ferrer-i-Carbonell, 2005, Clark et al., 2008, etc.). 
For example, Luttmer (2005) used US data from the National Survey of Families and Households and considered the neighbors' earnings as a reference to which individuals compare their earnings. The study suggests that the reference level has a negative impact on individuals' self-reported well-being. In particular, the magnitude of the effect on well-being of an increase in neighbors' earnings and that of a decrease in one's own income are roughly the same.

Individuals may compare their situation to an external reference (others) as well as an internal reference (one's past income or expected future income). Using the Spanish Continuous Family Expenditure Survey, Alvarez-Cuadrado et al. (2012) estimated the importance of the interdependence of preferences and habit persistence. Their results suggest that households' preferences derive almost $25 \%$ of their consumption services from comparison between their consumption and that of their neighbors, and around $35 \%$ from comparison between their current and past consumption. This implies that around $60 \%$ of individual satisfaction comes from relative consumption.

Contrary to a large number of studies containing data on developed countries which suggest a significant impact of relative income, some research using data on developing and low-income countries paints a different picture. In the latter, there is no systematically meaningful effect of relative concern on subjective well-being. Within a country, relative income matters differently for rich and poor people. The effect of relative standing on wellbeing is noticeable for the rich, while it may be absent for the poor. For the latter, the effect of absolute income is often more significant (Clark et al., 2008, Akay and Martinsson, 2011, Asadullah and Chaudhury, 2012). In particular, Asadullah and Chaudhury (2012) used data from rural Bangladesh to show that the relative wealth effect is stronger for the rich. However, when comparing the relative wealth effect to the absolute wealth effect, the results indicate that the relative wealth effect is lower. Using Malawian data, Ravallion and Lokshin (2010) found that relative income has no effect on the poor's subjective well-being. The same result was observed by Akay and Martinsson (2011) based on data from Ethiopia. For the rural areas of northern Ethiopia, one of the poorest regions in the world, relative income does not appear to matter at all. These studies using data on poor countries only show a significant effect of absolute income.

Focusing on the effect of relative consumption in the case of Nepal, Fafchamps and Shilpi (2008) gave two different findings based on the type of poor population. The authors concluded that the poor care less about relative consumption than the non-poor. However, when focusing on poor households that are isolated from markets, this conclusion changes. Households in isolated areas are more sensitive to their neighbors' standards of living. Moreover, controlling for a migration variable, the authors showed that household heads who have migrated from their birth district continue to compare their consumption with that of households in their district of origin.

Our study concerns 3 rural provinces in Vietnam and 3 rural provinces in Thailand. The next section provides some insights into the data about these two developing countries. 


\section{Data}

The data used in this paper comes from a rich survey database on "Impact of Shocks on the Vulnerability to Poverty: Consequences for Development of Emerging Southeast Asian Economies" in Vietnam and Thailand, collected by the DFG (German Research Foundation) FOR 756. Begun in 2007, the survey attempted to find a consensus on poverty and associated indicators that could affect poverty likelihood such as vulnerability, shocks and risks. The target population was poor rural households with a per capita income near the poverty line. To this end, we selected three peripheral provinces in Northeast Thailand (Buriam, Unbon Ratchathani, and Nakhon Phanom) and three provinces from the Central Highlands (Dak Lak) and the North Central and Central coastal area (Ha Tinh, Thua Thien Hue) in Vietnam. ${ }^{1,2}$

The three provinces in Thailand selected for our study are among the poorest in terms of infrastructure and access to essential services (e.g. electricity, public water, sanitation and public waste disposal). There is also high income inequality between the provinces of Thailand. This inequality is caused in particular by obstacles (e.g. poor transport links) that prevent goods and production output from circulating between regions (Limpanonda, 2012). As for Vietnam, the two regions mentioned are among the three poorest in the country. In 2010, the poverty rate was respectively $22.2 \%$ for Central Highland and $20.4 \%$ for the other region. It should be noted that these values are even higher than the average rural areas poverty rate of $17.5 \%$ and the whole country poverty rate of $14.2 \%$. As for the three provinces concerned, the poverty rate is $26.1 \%$ in Ha Tinh, $12.8 \%$ in Thua Thien Hue, and $21.9 \%$ in Dak Lak. These provinces also have a low population density and a low level of infrastructures and public services. ${ }^{3}$

Our analysis covers the 2010 wave of this survey. Table A1 in the Appendix summarizes the definition of variables concerning the socio-demographic and economic conditions of the households as well as environmental and economic events which occur during 2 years before the survey. Descriptive statistics are reported in Table A2 for the Vietnamese data and in Table A3 for the Thai data.

Two measures of household's subjective well-being were available in the data. They were defined in comparison to either the year before the survey or the 5 previous years. In response to the questions: "Do you think your household is better off than last year?" and "Do you think your household is better off than 5 years ago?", households were asked to report their answer on an increasing scale: 1 (much better off), 2 (better off), 3 (same as), 4 (worse off), and 5 (much worse off). Given that for both measures, categories 1 and 5 have very few observations, we then merged categories 1 and 2 into one group, and categories 4 and 5 into

\footnotetext{
${ }^{1}$ The survey area is illustrated in Figure A1.

2 For a more in-depth description of the sample, please refer to: https://www.vulnerability-asia.unihannover.de/6362.html

${ }^{3}$ E.g. In 2010, the density was 204 persons $/ \mathrm{km}^{2}$ in Ha Tinh, 215 in Thua Thien Hue, and 134 in Dak Lak, compared to 263 for the whole country. Accessibility to telephones was 7 persons per telephone in Ha Tinh, 5 in Thua Thien Hue, and 7 in Dak Lak compared to 0.7 for the whole country. For accessibility to public services such as health care, 601 persons shared a patient bed in Thua Thien Hue, 510 in Dak Lak, compared to 392 for the whole country. Source: Vietnam statistics yearbook 2010.
} 
another group to create two new 3-category variables. ${ }^{4}$ The first was subjective well-being compared to the previous year: $S W B=1$ if the household's well-being is worse or much worse than the previous year, $=2$ if it is the same as the previous year, $=3$ if it is better or much better. The other variable, subjective well-being compared to the 5 previous years, $S W B 5$, was defined similarly. The final dataset obtained from the 2010 wave included 1390 households (for both $S W B$ and $S W B 5$ ) from 199 villages in 3 Thai provinces (Buriram, Ubon Ratchathani and Nakhon Phanom) and 1201 households (for $S W B$ ) and 1198 households (for SWB5) observed in 152 villages in three Vietnamese provinces (Ha Tinh, Dak Lak and Thua Thien-Hue).

Table 1: Distribution of household subjective well-being

\begin{tabular}{l|cccc}
\hline & \multicolumn{3}{|c}{ Vietnam } & \multicolumn{2}{c}{ Thailand } \\
\hline Compared to the previous year $(S W B)$ & Frequency & Percent & Frequency & Percent \\
\hline Much worse or worse $(S W B=1)$ & 336 & 27.98 & 292 & 21.01 \\
Same $(S W B=2)$ & 494 & 41.13 & 537 & 38.63 \\
Better or much better $S W B=3)$ & 371 & 30.89 & 561 & 40.36 \\
\hline Compared to 5 previous years $(S W B 5)$ & & & & \\
\hline Much worse or worse $(S W B 5=1)$ & 269 & 22.45 & 323 & 23.34 \\
Same $(S W B 5=2)$ & 257 & 21.45 & 320 & 23.02 \\
Better or much better $(S W B 5=3)$ & 672 & 56.10 & 747 & 53.74 \\
\hline Note. Number of observations: $1201($ SWB) and 1198 (SWB5) for Vietnam, 1390 (both SWB and \\
\multicolumn{4}{c}{ SWB5) for Thailand. }
\end{tabular}

Table 1 reports the distribution of these two subjective variables $S W B$ and $S W B 5$. We note that when compared to the 5 previous years, a majority of households in both countries think that their situation is better or much better. However, compared to the previous year, the most frequent answer is "the same" (as the previous year) for Vietnamese households and "better or much better" for Thai households. Moreover, both in Vietnam and Thailand, Tables 3 and 4 show that households who feel "better or much better" than the previous year, also feel "better or much better" than the last five years (331 households in Vietnam and 490 in Thailand). This was also true for the "same" and the "worse/much worse" categories.

Table 3: Distribution of $S W B$ and $S W B 5$. Vietnam

\begin{tabular}{|l|ccc|c|}
\hline $\begin{array}{l}\text { Subjective well-being } \\
\text { compared to the } \\
\text { previous years }(\text { SWB })\end{array}$ & \multicolumn{3}{|c|}{$\begin{array}{c}\text { Subjective well-being compared to the 5 previous years } \\
\text { (SWB5) }\end{array}$} & \\
\cline { 2 - 5 } & Worse/much worse & Same & Better/much better & Total \\
\hline Worse/much worse & 189 & 65 & 81 & 335 \\
Same & 66 & 167 & 260 & 493 \\
Better/much better & 14 & 25 & 331 & 370 \\
\hline Total & 269 & 257 & 672 & 1198 \\
\hline
\end{tabular}

\footnotetext{
${ }^{4}$ In Vietnam, only 3 households $(0.25 \%$ of the sample said that their situation was "much better" compared to that of the previous year, and only $9(0.75 \%)$ said that the situation was "much worse", while only 66 Thai households (5\% of the sample) declared that their situation was "much better", and $20(1.4 \%)$ "much worse". When it came to comparison with the last five years, 42 Vietnamese households ( $4 \%$ of the sample) said that their actual situation was "much better" and 17 (1.4\%) "much worse". The statistics are respectively $131(9 \%)$ and $28(2 \%)$ in Thailand.
} 
Table 4: Distribution of $S W B$ and $S W B$ 5. Thailand

\begin{tabular}{|l|ccc|c|}
\hline \multirow{2}{*}{$\begin{array}{c}\text { Subjective well-being } \\
\text { compared to the } \\
\text { previous years }(\text { SWB })\end{array}$} & \multicolumn{2}{|c|}{$\begin{array}{c}\text { Subjective well-being compared to the 5 previous years } \\
\text { (SWB5) }\end{array}$} & \\
\cline { 2 - 5 } & Worse/much worse & Same & Better/much better & Total \\
\hline Worse/much worse & 212 & 38 & 42 & 292 \\
Same & 88 & 234 & 215 & 537 \\
Better/much better & 23 & 48 & 490 & 561 \\
\hline Total & 323 & 320 & 747 & 1390 \\
\hline
\end{tabular}

Table 5: Distribution of household subjective wealth

\begin{tabular}{l|cccc}
\hline & \multicolumn{3}{|c}{ Vietnam } & \multicolumn{2}{c}{ Thailand } \\
\hline Compared to the village & Frequency & Percent & Frequency & Percent \\
\hline Much worse or worse & 447 & 37.22 & 289 & 20.79 \\
Same & 577 & 48.04 & 915 & 65.83 \\
Better or much better & 177 & 14.74 & 186 & 13.38 \\
\hline Compared to country & & & & \\
\hline Much worse or worse & 731 & 60.87 & 719 & 51.73 \\
Same & 387 & 32.22 & 557 & 40.07 \\
Better or much better & 83 & 6.91 & 114 & 8.20 \\
\hline
\end{tabular}

Note. Number of observations: 1201 for Vietnam, 1390 for Thailand.

Table 5 describes the distribution of self-assessment of household wealth, compared to the village and to the country. Households were asked to estimate whether their wealth was better than the average of their village and then of their country. Compared to the village, the most frequent answer was "the same" as other households with $65.83 \%$ for Thai households and $48.04 \%$ for Vietnamese households. The most frequent answer in the comparison with the country was more pessimistic as $60.87 \%$ of the sampled Vietnamese households and $51.73 \%$ of the Thai households felt that their wealth was much worse or worse than that of other households. Interestingly, Table A6 in the Appendix indicates that among 177 Vietnamese households who felt "better/much better" at village level, only 71 also felt "better/much better" compared to country level, 47 of them even felt that their situation was "worse/much worse" and 59 "the same" compared to other Vietnamese residents outside of their village. The picture appears to be the same for Thai households (see A7 in the Appendix): only 57 of 186 households who felt "better/much better" at village level also felt "better/much better" at country level, while most of them thought their wealth was "worse/much worse" or "the same" compared to other country's resident categories.

Another subjective variable concerns the degree of risk acceptance. This concerns the self-assessment of general risk attitude. On an 11-point Likert scale, people were asked to respond to the question "Are you generally a person who is fully prepared to take risks (10) or do you try to avoid taking risks (0)?" A higher value in the answer corresponds to a higher degree of risk acceptance or a lower degree of risk aversion. In order to eliminate cases with an insufficient number of observations induced by the 11-point Likert scale, and to increase the variability of the risk variable, we referred to three levels of risk attitude: low risk acceptance (or risk avoidance), intermediate risk acceptance and high risk acceptance. We 
then created three dummies corresponding to three levels of risk attitude: Risk_Avoidance = 1 if the answer is $0,1,2$ or 3, Risk_Neutrality $=1$ if the answer is 4, 5, 6 or 7, and Risk_Acceptance $=1$ if the answer is 8,9 or 10 .

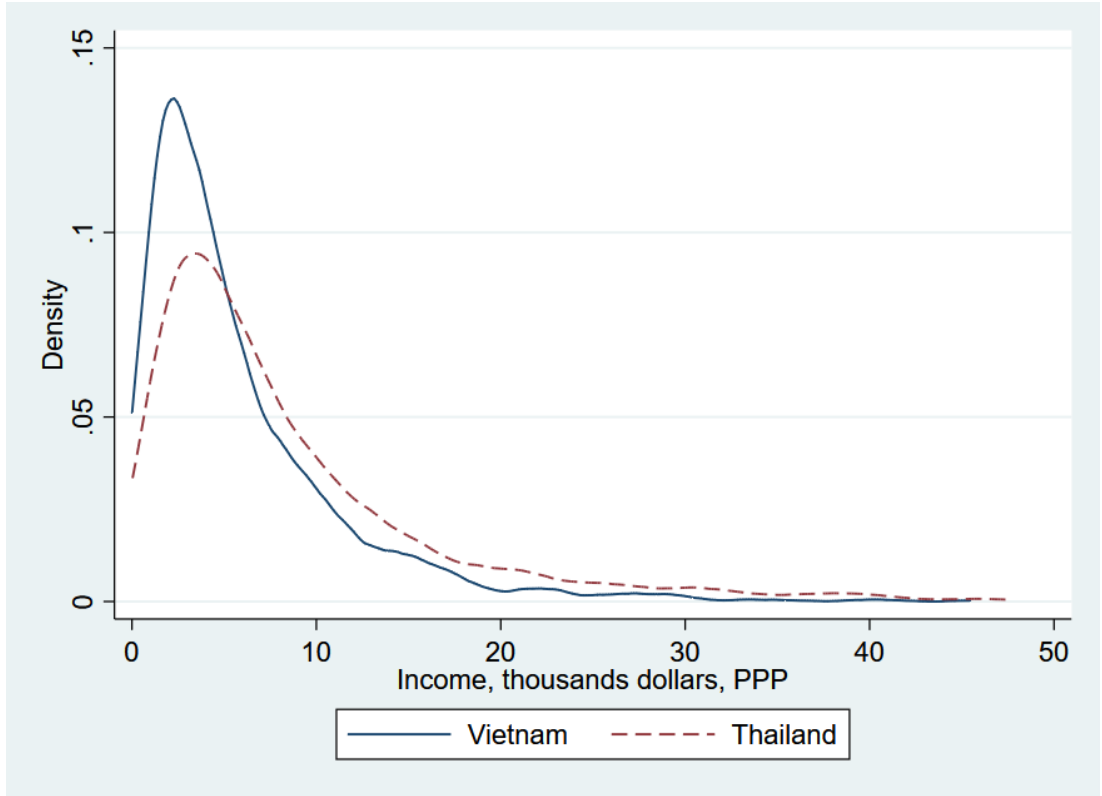

Figure 2: Distribution of total annual household income, in thousand dollars, PPP.

Figure 2 displays the distribution of total household income in 2010. We observe that Thai households are slightly richer than their Vietnamese counterparts as the Thai income distribution is on the right of the Vietnamese income distribution. Table A1 gives us 6.04 and 9.21 (in thousand dollars, PPP) for the average income of Vietnamese and Thai households, respectively. We created a dummy variable (Poor) to account for the relative poverty of households in the village: Poor is equal to 1 if household income is lower than the mean village level.

Table A1 also describes other variables regarding the households' characteristics (Mean village income, Average age in the household, Ethnic minority, health), living conditions (Access to electricity, Public water, Sanitation, Public waste disposal, Fixed phone line, and Internet), village characteristics (Mountain, Slope, Valley, Lake, Coast, Travel distance to district town) and province dummies. For Vietnam, the ethnic minority variable is a dummy variable with 0 if the household belongs to the Kinh majority group and 1 if it belongs to an ethnic minority. Given that the majority of Vietnamese belong to the Kinh ethnic group (one of 54 ethnics) with around $85 \%$ of the total population, this variable contains a majority of 0 , and about $15 \%$ of households belong to a minority ethnic. In the case of Thailand, Thai ethnicity accounts for $92 \%$ of the population, while the remaining $8 \%$ of the population belong to the other ethnic minorities. The dummy variable Minority contains a majority of 0 as only about $5.6 \%$ of Thai households in our data belong to an ethnic 
minority. Environmental risks (Drought, Flooding of land, Heavy ice rain, Storm) and economic shocks (Business collapse, Pests or livestock disease) are represented by dummies. These events occurred between May 2008 and April 2010, two years before the survey.

Focusing now on statistics at province level, Table A4 in the Appendix offers some important insights. On the one hand, natural shocks appear not to be equally distributed between the three provinces. In Vietnam, Dak Lak's villages are considered to be the most affected by Flooding of land, and Thua Thien Hue by Storm, landslide, while in Thailand, Buriam's villages and Nakhon Phanom's villages are the most vulnerable to Flooding of land. ${ }^{5}$ In terms of subjective well-being comparison with the previous year, Dak Lak and Thua Thien Hue households were more pessimistic since most of them declared that their situation was "worse/much worse", leading to an average index below 2 (i.e. "the same"). In contrast, Ha Tinh's households were more optimistic about their situation, and the same was true for the three Thai province households.

To gain deeper insights into Vietnamese and Thai villages, it is useful to see how these villages have evolved. To this end, we referred to the 2007 wave: the statistics are displayed in Table A5 in the Appendix. By comparing Table A4 with Table A5, we first observe that the poverty rate increased in both countries. In three Vietnamese provinces, $51 \%$ of households had an annual income lower than the average village income in 2007, and this statistic increased to $61 \%$ in 2010 . In three Thai provinces, the poverty rate was $58 \%$ in 2007 and $61 \%$ in 2010. Note that the picture remains the same when it comes to province levels. For example, in Ha Tinh in Vietnam, the poverty ratio increased from 54\% in 2007 to $62 \%$ in 2010. Second, in terms of subjective well-being, Vietnamese village households were less pessimistic in 2010 than in 2007, while the reverse was true for Thai village households.

\section{Econometric specifications}

\subsection{Relative utility function}

Let us consider the general utility function of households $i, i=1, \ldots, N$ :

$$
U_{i}=U\left(y_{i}, \bar{y}, w_{i}, \bar{w}, X_{i}\right)
$$

where $y_{i}$ is household income, $\bar{y}$ is a reference income level used for comparative purposes (e.g., average income of household $i$ 's village, region or country), $w_{i}$ household wealth, $\bar{w}$ a wealth reference (e.g., average wealth of household $i$ 's village), and $X_{i}$ the set of other observed determinants. The components of $X_{i}$ will be discussed below. The choice of this households' utility function depending on the average level of wealth and average level of

\footnotetext{
${ }^{5}$ Note that the Vietnamese declaration is likely to be consistent with objective sources and other research. For example, Arouri et al. (2015) claim that the incidence of households affected by storms and flooding is highest in the Central Highland and the North Central and Central coastal area. Likewise, according to the Vietnamese statistics yearbook 2010, total annual rainfall in Hue (a commune of Thua Thien Hue) and Pleiku (a rain gauge of the Central Highland and about 100km from Dak Lak) is among the highest in the country. In contrast, the Thai household's declaration appears to differ from the country's meteorological statistics. For example, the Thailand 2013 statistics yearbook reports that in 2010, the three provinces mentioned had high annual rainfall as well as a high number of rainy day, while in this study, a very small proportion of households (less than $1 \%$ ) declared that they suffered from undue rainfall.
} 
income reflects the comparison situation (Clark and Oswald, 1996, Frey and Stutzer, 2002, Luttmer, 2005, Akay and Martisson, 2011, etc.). People derive satisfaction not only from their absolute position in terms of material conditions but also from their relative position compared with their peers. In this case, the average level of income $\bar{y}$ and that of wealth $\bar{w}$ are considered as reference levels to which households compare their absolute level. A negative impact of a reference level on a households' well-being implies that there is an interpersonal comparison. The higher the reference level, the lower the households' utility, all other things being equal.

This general form of the utility function can be modified to fit in with the available data. Indeed, working with data on rural Vietnam and Thailand, information on household wealth $w_{i}$ and reference wealth $\bar{w}$ are not provided separately. The only information available is a subjective assessment of wealth, corresponding to the households' subjective estimation of their wealth in comparison with other residents at village level or with other residents at country level. This results in a binary indicator expressing whether the household is wealthier or not compared to the average village or country level. Hence, we adapt the utility function in (1) to account for this information from our data as follows:

$$
U_{i}=U\left(y_{i,}, \bar{y}, v\left(w_{i}, \bar{w}\right), X_{i}\right)
$$

where the indicator component $v\left(w_{i}, \bar{w}\right)=1\left(w_{i}<\bar{w}\right)$ states whether household $i$ is poorer compared to the average wealth level $\bar{w}$ (either at village or country level).

We can also use a binary indicator for income comparison as follows:

$$
U_{i}=U\left(u\left(y_{i}, \bar{y}\right), v\left(w_{i}, \bar{w}\right), X_{i}\right)
$$

where $u\left(y_{i}, \bar{y}\right)=1\left(y_{i}<\bar{y}\right)$ gives the information that household $i$ has an income level lower or higher than the reference income $\bar{y}$. In the next section, we employ the dummy variable Poor, which defines whether a household is poor or not (when its income is lower or higher than the average village income $\bar{y}$ ).

It should be noted that subjective well-being is reported in our data as a variation compared to the previous year or the 5 previous years ( $S W B$ or $S W B 5$ ). Therefore, we should interpret the utility accordingly. Let $U_{i 1}^{*}$ denote household $i$ 's unobserved (or latent) wellbeing at the time of the survey. We assume that $U_{i 1}^{*}$ is described by the following dynamic conditional model:

$$
U_{i 1}^{*}=z_{i 1}^{\prime} \beta+\lambda U_{i 0}^{*}+\varepsilon_{i 1},
$$

where $U_{i 0}^{*}$ is the household's unobserved well-being in the past and parameter $\lambda$ measures the persistent impact of past well-being. Note that data on $U_{i 0}^{*}$ are not available due to the survey design which does not contain any questions on the level of well-being at the current period. Indeed, the survey only contains questions about changes in well-being relative to the past (previous year or 5 previous years). 
By taking the difference between the current and past levels of well-being into the equation (4), we can express changes in well-being as follows:

$$
\Delta U_{i}^{*} \equiv U_{i 1}^{*}-U_{i 0}^{*}=z_{i 1}^{\prime} \beta+(\lambda-1) U_{i 0}^{*}+\varepsilon_{i 1} .
$$

This equation states that the variation in well-being $\left(\Delta U_{i}^{*}\right)$ depends on a set of observed variables at the current period $\left(z_{i 1}\right)$, the past level of well-being $\left(U_{i 0}^{*}\right)$ and an unobserved error term $\left(\varepsilon_{i 1}\right.$, assumed normally distributed $\left.\mathrm{N}\left(0, \sigma_{\varepsilon}^{2}\right)\right)$. Remember that $\Delta U_{i}^{*}$ is what we want to measure but it is not observed. We can link $\Delta U_{i}^{*}$ to the observed measures of variation in subjective well-being with respect to the past (i.e. $S W B$ and $S W B 5$ ) by using the following ordered probit model

$$
D U_{i}=\left\{\begin{array}{l}
1 \text { if } \Delta U_{i}^{*} \leq c_{1} \\
2 \text { if } c_{1}<\Delta U_{i}^{*} \leq c_{2} \\
3 \text { if } c_{2}<\Delta U_{i}^{*}
\end{array}\right.
$$

where $D U_{i}$ corresponds to the observed changes in subjective well-being reported by household $i$ (either $S W B$ or $S W B 5$ ) and $\Delta U_{i}^{*}$ is defined by equation (5).

Because of the presence of an unobserved variable $\left(U_{i 0}^{*}\right)$ on the right-hand side of equation (5) besides the error term $\varepsilon_{i 1}$ (which is assumed to be independent and identically distributed and independent of $z_{i 1}$ ), the model estimation cannot be directly performed using the standard ordered probit model. Some additional assumptions need to be included for identification purposes. Indeed, as $U_{i 0}^{*}$ is unobserved, we need to make an assumption about its distribution. A reasonable assumption is a conditional form for $U_{i 0}^{*}$ (similar to correlated random effects in a panel data framework):

$$
U_{i 0}^{*}=x_{i}^{\prime} \gamma+v_{i}
$$

where $x_{i}$ includes a set of individual characteristics (time-invariant regressors) and $v_{i}$ an error term which can either be independent or correlated with $\varepsilon_{i 1}$ (assumed to be normally distributed $\left.\mathrm{N}\left(0, \sigma_{v}^{2}\right)\right){ }^{6}$ In order to work with changes in well-being, we combine equations (5) and (7):

$$
\Delta U_{i}^{*}=z_{i 1}^{\prime} \beta+x_{i}^{\prime} \gamma(\lambda-1)+(\lambda-1) v_{i}+\varepsilon_{i 1}
$$

This is the same ordered probit model as in equation (5) but with the new error term $(\lambda-$ 1) $v_{i}+\varepsilon_{i 1}$. Using a normalization for the variance, $\operatorname{Var}\left[(\lambda-1) v_{i}+\varepsilon_{i 1}\right]=1$ (whether $v_{i}$ and $\varepsilon_{i 1}$ are independent or not), this model is reduced to the standard ordered probit applied to equations (6) and (8): we regress changes in well-being on two sets of variables, currentperiod variables $z_{i 1}$ and time invariant variables $x_{i}$. Note that these explanatory variables correspond to $X_{i}$ in equations (1) - (3). This estimation delivers parameters $\beta$ (the intercept is

\footnotetext{
${ }^{6}$ If we substitute (7) in (4), we obtain the regression model corresponding to the utility function in (3), where $z_{i 1}$ includes variables relative to comparisons (the first two arguments of the utility function) and $x_{i}$ the third argument.
} 
normalized to zero), $\tilde{\gamma}$ ( $\equiv \gamma(\lambda-1)$, for $\gamma$ and $\lambda-1$ are not separately identified), and the thresholds $\left(c_{1}\right.$ and $\left.c_{2}\right)$.

Alternatively, we can add the independence between $v_{i}$ and $\varepsilon_{i 1}$, leading to another estimation procedure which corresponds to an ordered probit model with unobserved heterogeneity $v_{i}$. The model's log-likelihood in this case is

$$
\ln L=\sum_{i=1}^{N} \ln \int\left[\prod_{j=1}^{3} \operatorname{Pr}\left(D U_{i}=j \mid z_{i 1}, w_{i}, v_{i}\right)^{1\left(D U_{i}=j\right)}\right] f\left(v_{i}\right) d v_{i}
$$

where $1($.$) is the indicator function for the state of variation in well-being \left(D U_{i}=j\right)$ and $f($. is the density of unobserved heterogeneity for $v_{i}$. The latter is integrated out before maximization. In practice, we compute this integration by simulation (using a high number of replications, e.g. 50 or 100). Note that, besides $\beta$ and the thresholds $c_{1}$ and $c_{2}$, this model allows us to separately identify $\lambda-1$ and $\gamma$.

In estimations, the set of explanatory variables $z_{i 1}$ encompasses all the variables included in the arguments of the utility function, i.e., $y_{i}, \bar{y}, 1\left(w_{i}, \bar{w}\right)$. More precisely, $y_{i}$, corresponds to total annual household income and $\bar{y}$ corresponds to average household income at village level. Estimations also include the case where $y_{i}$ and $\bar{y}$ are replaced by the income comparison binary indicator $u\left(y_{i}, \bar{y}\right)=1\left(y_{i}<\bar{y}\right)$, denoted Poor as above. The regression with Poor also includes its interaction with Income (i.e. Poor*Income) to account for the asymmetric effect of Income on households' subjective well-being. The set $x_{i}$ includes time-invariant variables like economic and environmental risks, degree of risk acceptance, a dummy indicating the household head suffers from a serious disease, average age in the household, a dummy for ethnic minority, percentages for access to various facilities (electricity, public water supply, sanitation, public waste disposal, fixed phone line and internet), dummies for geographical characteristics of household $i$ 's village (on a mountain, on a slope, in a valley, near a river, near a lake, on the coast and travel distance to district town), and dummies for provinces (Dak Lak and Nakhon Phanom provinces are used as references for the Vietnamese and Thai data, respectively).

\subsection{Endogenous regressors}

Let us recall that we can estimate both alternative specifications above -- (i) the standard ordered probit model in equations (6) and (8), and (ii) the ordered probit model with unobserved heterogeneity, of which the log-likelihood function given in equation (9) -- by maximum likelihood using village-clustered robust standard errors. Before going further, the issue of endogenous regressors needs to be discussed as its existence can bias the results. More precisely, household income, income comparison indicators (i.e. Poor), interaction between Poor and Income, and Risk Attitude (Risk Avoiding and Risk Acceptance) are potentially endogenous as they can be affected by unobserved factors. ${ }^{7}$ In order to fix this issue in the ordered probit model, we use the 'variable addition test' based on the control function approach proposed by Wooldridge (2014) to test for exogeneity of explanatory

\footnotetext{
${ }^{7}$ Risk neutrality is used as a reference.
} 
variables in nonlinear models. This can be implemented using the following two-step procedure:

First, for the regression with income $\left(y_{i}\right)$ and mean village income $(\bar{y})$, denoted Model 1, we made: (i) a linear regression of Income (as it is a continuous variable), and (ii) a probit regression of Risk avoidance on the one hand, and Risk acceptance on the other, for the whole set of the model's explanatory variables and additional instruments (that are excluded from the model). For the Income regression, excluded instruments correspond to a dummy indicating the household head's ability to read and write, a dummy for the main occupation as agriculture, a dummy for membership of a political association (Communist Party, professional association, etc.), a continuous variable for the house value, and finally a variable for the proportion of males in the household. ${ }^{8}$ These excluded instruments are also considered in the probit regressions of household risk attitude (i.e. Risk avoidance and Risk acceptance). Indeed, the household head's ability to read and write can be considered as his/her human capital while the dummy for membership of a political association reflects the household's social networks. These variables are assumed to be correlated with the endogenous variables. Likewise, the main occupation of the household head, the house value or the proportion of males in the household may affect household income or risk attitude. They are assumed not to be correlated with the observed changes in subjective well-being reported by household $i$ (either $S W B$ or $S W B 5$ ).

For the regression with income comparison indicator (i.e. Poor), denoted Model 2, we applied a probit regression to Poor (as it is a binary variable), Risk avoidance and Risk acceptance. The interaction term between poor and income was also instrumented by a linear regression. The set of explanatory variables and excluded instruments for Poor, Income, Poor*Income, Risk avoidance, and Risk acceptance were similarly defined as above.

Second, we computed the generalized residuals for these regressions of the first step and performed the ordered probit regression using these generalized residuals as additional explanatory variables. More precisely, we included generalized residuals corresponding to Income, Risk avoidance and Risk acceptance in Model 1, on the one hand, and those corresponding to Income, Poor, Poor*Income, Risk avoidance and Risk acceptance in Model 2 , on the other.

Finally, as recommended by Wooldridge (2014), a (village clustered) robust $t$-test for the null hypothesis showed that the coefficient of residuals was zero. The null hypothesis corresponds to the exogeneity of Income, Poor, Poor*Income, Risk avoidance and Risk acceptance. The test is termed 'robust' as it is based on robust standard errors.

\section{Estimation results}

It should be recalled that we used two different models to represent the social comparison: Model 1 with mean village income as a reference level to which households compare their income and Model 2 with a relative poverty binary indicator. Regressions were performed

\footnotetext{
${ }^{8}$ Communist Party concerns only Vietnamese households.
} 
with two measures of subjective well-being: $S W B$ is the household subjective well-being compared to the previous year, and SWB5 is the household subjective well-being compared to the 5 previous years.

For each subjective well-being measure, we estimated two variants of the ordered probit model (the standard ordered probit model and the model with unobserved heterogeneity $v_{i}$ as discussed in Section 4.1). A likelihood ratio test (following a $\chi^{2}(1)$ distribution) was computed to choose the best specification. Table A8 shows that the standard ordered probit model is preferred to the model with unobserved heterogeneity (the test statistic is always lower than the 5\% critical value, 3.84). Therefore, in the following, we only discuss estimations of the standard ordered probit model.

Furthermore, almost none of the computed robust $t$-statistics of the variable addition test for exogeneity of Income, Poor, interaction term Poor*Income, and risk attitude (Risk avoidance and Risk acceptance) reject exogeneity in Models 1 and 2 for the two measures $S W B$ and SWB5 or for the two countries. There are only two exceptions: the exogeneity of Poor is rejected at the 5\% level for SWB5 in Vietnam and that of Risk acceptance for SWB in Thailand is rejected at the $10 \%$ level. If we perform the joint significance test (following a chi-squared distribution) for these regressors, no test passes the 5\% level. Thus, for simplicity's sake, we report the estimation results for the model with exogenous explanatory variables (even for the case of Poor in the regression of SWB5 with Vietnamese data.

All the estimated coefficients of the models are provided in Tables A10-A11 in the Appendix, where we also report the results of the first step regressions (Tables A12-A15). The marginal effects of some significant explanatory variables are reported in Tables 3-6. Note that the marginal effect of an explanatory variable is calculated by maintaining other variables at their average values. ${ }^{9}$ The results show that income is one of the key determinants of household happiness in both countries. A higher income is conducive to a higher probability of feeling better off or much better off ( $S W B=3$ or $S W B 5=3)$ compared to the past (1 or 5 previous years). More specifically, if household income increases by 1 thousand dollars (in either country), the chance of attaining higher satisfaction increases by $0.5 \%$ to $1.8 \%$ (compared to the previous year) or by $0.6 \%$ to $2 \%$ (compared to the previous 5 years). However, the income of other households living in the same village does not matter for both countries (Model 1). Moreover, when observing the results of Model 2, the interaction term Poor*Income is positive and significant, reflecting an asymmetric effect of income, i.e. the income effect is higher for the poor than for the rich.

When analyzing the effects of relative poverty (Model 2), we observe a phenomenon of social comparison in terms of income. The estimation results reported in Tables A11-A12 show that households in both countries are sensitive to relative poverty as this variable exerts a negative and significant effect on their subjective well-being compared to the previous year $(S W B)$ and the 5 previous years (SWB5). This result is confirmed when analyzing the marginal

\footnotetext{
${ }^{9}$ Note that marginal effects of a variable on different probabilities, $\partial P\left(D U_{i}=l\right) / \partial z_{i j}$ where $l=1,2,3$ add up to 0, i.e. $\sum_{l=1}^{3} \partial P\left(D U_{i}=l\right) / \partial z_{i j}=0$.
} 
effects of these two variables. For example, Table 5 (Model 2) indicates that for Vietnam, relative poverty (earning an income lower than the mean village level) makes households feel worse off than in the 5 previous years. More precisely, it has a negative effect on the probability of inducing a high level of subjective well-being, SWB5 $=3$ (better or much better), while it has a positive effect on the probability of inducing a lower level of wellbeing, $S W B 5=1$ (worse or much worse off), $S W B 5=2$ (same). Likewise, Table 6 gives us the same observation regarding the marginal effects of relative poverty for Thailand.

Observations regarding the subjective self-assessment of household wealth showed considerable disparity between the two countries. We found that Thai households were concerned by wealth comparison while Vietnamese households are not. Indeed, the effect of self-assessment of wealth comparison at country level was meaningful for both measures of well-being, i.e., $S W B$ and $S W B 5$, in the Thailand case. This implies that households feel happier if they estimate their wealth is better than that of other residents at country level. Tables 4 and 6 indicate that a higher self-assessment of wealth increases the probability of giving a high value of subjective well-being $(S W B=3$ or $S W B 5=3)$ and decreases the probability of giving a lower value of subjective well-being $(S W B=1, S W B=$ 2 or $S W B 5=1, S W B 5=2$ ), all other things being equal.

The estimation also shows that comparison at village level does not exist. This difference between village and country level might be interpreted as an asymmetry of social comparison in terms of wealth and, in particular, the comparison is upward. Indeed, we noted that since our data is composed of rural and poor provinces in Thailand, a comparison with other residents at country level may be viewed as a comparison with a high reference. ${ }^{10}$ In this sense, considering themselves as wealthier than others at country level may increase the households' subjective well-being.

Let us now consider variables concerning environmental risks such as drought, flooding, heavy ice rain and storms, ${ }^{11}$ events that occurred in the past, 2 years before the survey. Analyses indicate that drought, flooding and heavy ice rain in the past increase good feelings in the present for Vietnamese households, while drought in the past increases good feelings in the present for Thai households. It is not surprising to find that environmental risks in the past have a positive effect on the fact that households feel better off than one year ago or in the 5 previous years. In other words, when looking at natural disasters in the past, households feel better off in the present. In addition, when considering two economic shocks, pests or livestock disease and collapse of business 2 years before the survey, only the pests or livestock disease appear meaningful for the Thai households' subjective well-being.

Linked to these environmental and economic events, we are interested in the effect of households' risk attitude. This variable measures the degree of risk acceptance: a higher value implies a higher degree of acceptance and lower risk aversion. The estimated coefficient shows a difference between the two countries in this variable's effect. In the Vietnam case, we

\footnotetext{
${ }^{10}$ This result may be refereed to Tsui (2014) which proposes 2 reference levels, a high level and a low one. Tsui (2004) showed that individuals compare their income to the high reference rather to the low one.

${ }^{11}$ For Thailand, we do not take into account "heavy ice rain" as this variable has few observations.
} 
observe that that those who are less risk averse feel better off in the present than in the previous year or 5 previous years, ceteris paribus. For Thailand, this variable has no effect.

We also observe a difference in the effects of other variables on households' subjective well-being in both countries. Regarding living conditions, we find that the subjective well-being of Vietnamese households in a village increases with the proportion of households having access to electricity. Other living conditions such as access to a public water supply, sanitation, internet, etc. have no impact on either Thai or Vietnamese households' well-being. Households living in different geographic conditions may feel their happiness differently. While people living on a mountain are happier in the case of Vietnam, they are less happy in the case of Thailand. However, living near a river can decrease good feelings for Vietnamese households, while it tends to have no effect on good feelings for Thai households.

Concerning the different provinces in our data, for Vietnam, households in Ha Tinh province may feel better off than the previous year compared to those living in the Dak Lak province (all other things being equal). For Thailand, households in the Buriram province are less happy compared to the past (1 or 5 previous years), while households in Ubon Ratchathan are happier compared to the previous year (with Nakhon Phanom province as a reference). 
Table 3: Marginal effects, the case of $S W B$, Vietnam.

\begin{tabular}{|c|c|c|c|c|c|c|}
\hline \multirow[b]{2}{*}{ Variable } & \multicolumn{3}{|c|}{ Model 1} & \multicolumn{3}{|c|}{ Model 2} \\
\hline & $P(S W B=1)$ & $P(S W B=2)$ & $P(S W B=3)$ & $P(S W B=1)$ & $P(S W B=2)$ & $P(S W B=3)$ \\
\hline \multirow[t]{2}{*}{ Income } & $-0.0076 * * *$ & -0.0005 & $0.0081 * * *$ & $-0.0149 * * *$ & $-0.0033 * *$ & $0.0183 * * *$ \\
\hline & $(0.0022)$ & $(0.0004)$ & $(0.0024)$ & $(0.0037)$ & $(0.0017)$ & $(0.0052)$ \\
\hline \multirow[t]{2}{*}{ Mean village income } & 0.0009 & 0.0000 & -0.0010 & -- & -- & -- \\
\hline & $(0.0050)$ & $(0.0003)$ & $(0.0053)$ & & & \\
\hline \multirow[t]{2}{*}{ Poor } & -- & -- & & 0.00641 & 0.00147 & -0.0079 \\
\hline & & & & $(0.0298)$ & $(0.0068)$ & $(0.0366)$ \\
\hline \multirow{2}{*}{$\begin{array}{l}\text { Subjective wealth, wrt } \\
\text { village }\end{array}$} & 0.0123 & 0.0007 & -0.0130 & 0.0178 & 0.0040 & -0.0218 \\
\hline & $(0.0195)$ & $(0.0013)$ & $(0.0206)$ & $(0.0179)$ & $(0.0041)$ & $(0.0219)$ \\
\hline \multirow{2}{*}{$\begin{array}{l}\text { Subjective wealth, wrt } \\
\text { country }\end{array}$} & -0.0332 & -0.0019 & 0.0351 & -0.0264 & -0.0059 & 0.0324 \\
\hline & $(0.0231)$ & $(0.002)$ & $(0.0245)$ & $(0.0215)$ & $(0.00500)$ & $(0.0262)$ \\
\hline \multirow[t]{2}{*}{ Drought } & $-0.0687 *$ & -0.004 & $0.0728 *$ & $-0.0686^{*}$ & $-0.0154 *$ & $0.0840 * *$ \\
\hline & $(0.0383)$ & $(0.0035)$ & $(0.0405)$ & $(0.0353)$ & $(0.0086)$ & $(0.0426)$ \\
\hline \multirow[t]{2}{*}{ Flooding } & $-0.101 * * *$ & -0.0059 & $0.107 * * *$ & $-0.0877 * * *$ & $-0.0197 * *$ & $0.107 * * *$ \\
\hline & $(0.0356)$ & $(0.0045)$ & $(0.0375)$ & $(0.0334)$ & $(0.0092)$ & $(0.0405)$ \\
\hline \multirow[t]{2}{*}{ Heavy rain } & $-0.105^{* *}$ & -0.0062 & $0.111 * *$ & $-0.0885^{*}$ & $-0.0199 *$ & $0.108^{*}$ \\
\hline & $(0.0526)$ & $(0.0052)$ & $(0.0556)$ & $(0.0487)$ & $(0.0121)$ & $(0.0592)$ \\
\hline \multirow[t]{2}{*}{ Storm, landslide } & 0.0546 & 0.0032 & -0.0579 & 0.0420 & 0.00945 & -0.0515 \\
\hline & $(0.0402)$ & $(0.0032)$ & $(0.0425)$ & $(0.0375)$ & $(0.0088)$ & $(0.0458)$ \\
\hline \multirow[t]{2}{*}{ Pests or livestock disease } & $-0.0492 *$ & -0.0029 & $0.0521 *$ & $-0.0471 *$ & -0.0106 & $0.0576^{*}$ \\
\hline & $(0.0295)$ & $(0.0025)$ & $(0.0310)$ & $(0.0272)$ & $(0.0065)$ & $(0.0328)$ \\
\hline \multirow[t]{2}{*}{ Collapse of business } & -0.0633 & -0.0038 & 0.0671 & -0.0427 & -0.0096 & 0.0523 \\
\hline & $(0.0966)$ & $(0.0061)$ & $(0.102)$ & $(0.0837)$ & $(0.0185)$ & $(0.102)$ \\
\hline \multirow[t]{2}{*}{ Risk avoidance } & $0.102 * * *$ & 0.0061 & $-0.108 * * *$ & $0.0898 * * *$ & $0.0202 * * *$ & $-0.110 * * *$ \\
\hline & $(0.0223)$ & $(0.0042)$ & $(0.023)$ & $(0.0208)$ & $(0.0068)$ & $(0.0242)$ \\
\hline \multirow[t]{2}{*}{ Risk acceptance } & $-0.180 * * *$ & -0.0107 & $0.190 * * *$ & $-0.169 * * *$ & $-0.0381 * *$ & $0.207 * * *$ \\
\hline & $(0.0378)$ & $(0.008)$ & $(0.0412)$ & $(0.0343)$ & $(0.0153)$ & $(0.0448)$ \\
\hline \multirow{2}{*}{$\begin{array}{l}\text { Suffering from serious } \\
\text {.. }\end{array}$} & $0.0380 *$ & 0.0022 & $-0.0402 *$ & $0.0358^{*}$ & $0.0081 *$ & $-0.0439 *$ \\
\hline & $(0.0204)$ & $(0.0019)$ & $(0.0216)$ & $(0.0189)$ & $(0.0046)$ & $(0.0228)$ \\
\hline \multirow[t]{2}{*}{ Access to electricity } & $-0.263 * * *$ & -0.0156 & $0.279 * * *$ & $-0.224 * * *$ & $-0.0503 * *$ & $0.274 * * *$ \\
\hline & $(0.0735)$ & $(0.0118)$ & $(0.0782)$ & $(0.0687)$ & $(0.0208)$ & $(0.0831)$ \\
\hline \multirow[t]{2}{*}{ Travel distance to district } & -0.0011 & -0.000 & 0.0011 & -0.0008 & -0.0002 & 0.001 \\
\hline & $(0.0012)$ & $(0.000$ & $(0.0012)$ & $(0.001)$ & $(0.0002)$ & $(0.0013)$ \\
\hline \multirow[t]{2}{*}{ Mountain } & $-0.064 * *$ & -0.0038 & $0.0678 * *$ & $-0.0589 * *$ & $-0.0132 * *$ & $0.0721 * *$ \\
\hline & $(0.0265)$ & $(0.0028)$ & $(0.0276)$ & $(0.0247)$ & $(0.0062)$ & $(0.0296)$ \\
\hline
\end{tabular}

Note: Model 1 corresponds to regressions with Income and Mean village income. Model 2 corresponds to regressions with Income and Poor (including their interaction). All explanatory variables are exogenous. Significance levels: $* * 5 \%, * * * 1 \%$. Number of observations: 1201. 
Table 4: Marginal effects, the case of $S W B$, Thailand.

\begin{tabular}{|c|c|c|c|c|c|c|}
\hline \multirow[b]{2}{*}{ Variable } & \multicolumn{3}{|c|}{ Model 1} & \multicolumn{3}{|c|}{ Model 2} \\
\hline & $P(S W B=1)$ & $P(S W B=2)$ & $P(S W B=3)$ & $P(S W B=1)$ & $P(S W B=2)$ & $P(S W B=3)$ \\
\hline \multirow[t]{2}{*}{ Income } & $-0.0040 * * *$ & $-0.0015 * * *$ & $0.0054 * * *$ & $-0.0080 * * *$ & $-0.0043 * * *$ & $0.0124 * * *$ \\
\hline & $(0.0013)$ & $(0.0005)$ & $(0.0017)$ & $(0.0020)$ & $(0.0015)$ & $(0.0035)$ \\
\hline \multirow[t]{2}{*}{ Mean village income } & -0.0008 & -0.0003 & 0.0011 & -- & -- & -- \\
\hline & $(0.0012)$ & $(0.0004)$ & $(0.0017)$ & & & \\
\hline \multirow[t]{2}{*}{ Poor } & -- & -- & -- & -0.0034 & -0.0018 & 0.0052 \\
\hline & & & & $(0.0226)$ & $(0.0122)$ & $(0.0349)$ \\
\hline \multirow{2}{*}{$\begin{array}{l}\text { Subjective wealth, wrt } \\
\text { village }\end{array}$} & 0.0022 & 0.0008 & -0.0030 & 0.0054 & 0.0029 & -0.0084 \\
\hline & $(0.0157)$ & $(0.0058)$ & $(0.0215)$ & $(0.0142)$ & $(0.0078)$ & $(0.0220)$ \\
\hline \multirow{2}{*}{$\begin{array}{l}\text { Subjective wealth, wrt } \\
\text { country }\end{array}$} & $-0.0389 * *$ & $-0.0143 * *$ & $0.0533 * *$ & $-0.0347 * *$ & $-0.0188 * *$ & $0.0535 * *$ \\
\hline & $(0.0151)$ & $(0.0058)$ & $(0.0208)$ & $(0.0139)$ & $(0.0077)$ & $(0.0212)$ \\
\hline \multirow[t]{2}{*}{ Drought } & $-0.0575^{* *}$ & $-0.0212 * *$ & $0.0787 * *$ & $-0.0476^{* *}$ & $-0.0258 * *$ & $0.0735 * *$ \\
\hline & $(0.0232)$ & $(0.0084)$ & $(0.0313)$ & $(0.0211)$ & $(0.0114)$ & $(0.0321)$ \\
\hline \multirow{2}{*}{ Flooding } & 0.0054 & 0.0020 & -0.0075 & 0.0072 & 0.0039 & -0.0111 \\
\hline & $(0.0305)$ & $(0.0112)$ & $(0.0417)$ & $(0.0278)$ & $(0.0151)$ & $(0.0428)$ \\
\hline \multirow[t]{2}{*}{ Storm, landslide } & -0.1079 & -0.0398 & 0.1477 & -0.0991 & -0.0538 & 0.1529 \\
\hline & $(0.0929)$ & $(0.0343)$ & $(0.1270)$ & $(0.0867)$ & $(0.0476)$ & $(0.1338)$ \\
\hline \multirow[t]{2}{*}{ Pests or livestock disease } & -0.0607 & -0.0224 & 0.0831 & -0.0524 & -0.0284 & 0.0808 \\
\hline & $(0.0428)$ & $(0.0161)$ & $(0.0587)$ & $(0.0382)$ & $(0.0213)$ & $(0.0592)$ \\
\hline \multirow[t]{2}{*}{ Collapse of business } & 0.0380 & 0.0140 & -0.0520 & 0.0369 & 0.0200 & -0.0568 \\
\hline & $(0.0756)$ & $(0.0277)$ & $(0.1033)$ & $(0.0691)$ & $(0.0374)$ & $(0.1064)$ \\
\hline \multirow[t]{2}{*}{ Risk avoidance } & 0.0265 & 0.0098 & -0.0363 & 0.0218 & 0.0118 & -0.0337 \\
\hline & $(0.0191)$ & $(0.0070)$ & $(0.0260)$ & $(0.0178)$ & $(0.0094)$ & $(0.0270)$ \\
\hline \multirow[t]{2}{*}{ Risk acceptance } & -0.0201 & -0.0074 & 0.0274 & -0.0158 & -0.0086 & 0.0243 \\
\hline & $(0.0260)$ & $(0.0095)$ & $(0.0354)$ & $(0.0234)$ & $(0.0127)$ & $(0.0360)$ \\
\hline \multirow[t]{2}{*}{ Suffering from serious } & -0.0099 & -0.0036 & 0.0135 & -0.0067 & -0.0037 & 0.0104 \\
\hline & $(0.0216)$ & $(0.0080)$ & $(0.0296)$ & $(0.0197)$ & $(0.0107)$ & $(0.0304)$ \\
\hline \multirow[t]{2}{*}{ Access to public water } & $0.0451 *$ & $0.0166^{*}$ & $-0.0617 *$ & $0.0440 *$ & $0.0238 *$ & $-0.0678^{*}$ \\
\hline & $(0.0260)$ & $(0.0095)$ & $(0.0354)$ & $(0.0234)$ & $(0.0126)$ & $(0.0357)$ \\
\hline \multirow[t]{2}{*}{ Mountain } & $0.2229 * * *$ & $0.0822 * * *$ & $-0.3051 * * *$ & $0.1960 * * *$ & $0.1063 * * *$ & $-0.3023^{* * *}$ \\
\hline & $(0.0308)$ & $(0.0144)$ & $(0.0423)$ & $(0.0321)$ & $(0.0198)$ & $(0.0468)$ \\
\hline \multirow[t]{2}{*}{ Valley } & $0.1190 * * *$ & $0.0439 * * *$ & $-0.1629 * * *$ & $0.0969^{* * *}$ & $0.0525 * * *$ & $-0.1494 * * *$ \\
\hline & $(0.0225)$ & $(0.0111)$ & $(0.0327)$ & $(0.0208)$ & $(0.0136)$ & $(0.0326)$ \\
\hline \multirow[t]{2}{*}{ River } & $-0.0435^{*}$ & $-0.0160 *$ & $0.0596^{*}$ & $-0.0370 *$ & $-0.0201 *$ & $0.0571 *$ \\
\hline & $(0.0236)$ & $(0.0085)$ & $(0.0319)$ & $(0.0221)$ & $(0.0117)$ & $(0.0335)$ \\
\hline
\end{tabular}

Note: Model 1 corresponds to regressions with Income and Mean village income. Model 2 corresponds to regressions with Income and Poor (including their interaction). All explanatory variables are exogenous. Significance levels: $* 10 \% * *$ $5 \%$, *** $1 \%$. Number of observations: 1390. 
Table 5: Marginal effects, the case of SWB5, Vietnam.

\begin{tabular}{|c|c|c|c|c|c|c|}
\hline \multirow[b]{2}{*}{ Variable } & \multicolumn{3}{|c|}{ Model 1} & \multicolumn{3}{|c|}{ Model 2} \\
\hline & $P(S W B 5=1)$ & $P(S W B 5=2)$ & $P(S W B 5=3)$ & $P(S W B 5=1)$ & $P(S W B 5=2)$ & $P(S W B 5=3)$ \\
\hline Income & $\begin{array}{l}-0.0117 * * * \\
(0.0023)\end{array}$ & $\begin{array}{l}-0.0049 * * * \\
(0.0012)\end{array}$ & $\begin{array}{l}0.0166^{* * * *} \\
(0.0036)\end{array}$ & $\begin{array}{l}-0.0132 * * * \\
(0.0033)\end{array}$ & $\begin{array}{l}-0.0073 * * * \\
(0.0025)\end{array}$ & $\begin{array}{l}0.0207 * * * \\
(0.0056)\end{array}$ \\
\hline Mean village income & $\begin{array}{l}0.0097 * \\
(0.005)\end{array}$ & $\begin{array}{l}0.004^{*} \\
(0.0021)\end{array}$ & $\begin{array}{l}-0.0137 * \\
(0.0071)\end{array}$ & -- & -- & -- \\
\hline Poor & -- & -- & -- & $\begin{array}{l}0.0336 * * \\
(0.017)\end{array}$ & $\begin{array}{l}-0.0898 * * \\
(0.0447)\end{array}$ & $\begin{array}{l}0.0336^{* *} \\
(0.017)\end{array}$ \\
\hline Subjective wealth, wrt & $\begin{array}{l}-0.00308 \\
(0.0179)\end{array}$ & $\begin{array}{l}-0.0013 \\
(0.0074)\end{array}$ & $\begin{array}{l}0.0044 \\
(0.0253)\end{array}$ & $\begin{array}{l}0.0051 \\
(0.0157)\end{array}$ & $\begin{array}{l}0.0033 \\
(0.0089)\end{array}$ & $\begin{array}{l}-0.0079 \\
(0.0246)\end{array}$ \\
\hline Subjective wealth, wrt & $\begin{array}{l}-0.0084 \\
(0.0207)\end{array}$ & $\begin{array}{l}-0.0035 \\
(0.0085)\end{array}$ & $\begin{array}{l}0.0118 \\
(0.0292)\end{array}$ & $\begin{array}{l}0.0004 \\
(0.0182)\end{array}$ & $\begin{array}{l}0.0008 \\
(0.0103)\end{array}$ & $\begin{array}{l}-0.0006 \\
(0.0285)\end{array}$ \\
\hline Flooding & $\begin{array}{l}-0.133 * * * \\
(0.0361)\end{array}$ & $\begin{array}{l}-0.0547 * * * \\
(0.0152)\end{array}$ & $\begin{array}{l}0.187 * * * \\
(0.0503)\end{array}$ & $\begin{array}{l}-0.114 * * * \\
(0.0322)\end{array}$ & $\begin{array}{l}-0.0657 * * * \\
(0.0183)\end{array}$ & $\begin{array}{l}0.179 * * * \\
(0.0485)\end{array}$ \\
\hline Heavy ice rain & $\begin{array}{l}-0.162 * * * \\
(0.0561)\end{array}$ & $\begin{array}{l}-0.067 * * * \\
(0.0229)\end{array}$ & $\begin{array}{l}0.229 * * * \\
(0.0781)\end{array}$ & $\begin{array}{l}-0.131 * * \\
(0.0522)\end{array}$ & $\begin{array}{l}-0.0707 * * \\
(0.0289)\end{array}$ & $\begin{array}{l}0.205^{* * * *} \\
(0.079)\end{array}$ \\
\hline Storm, landslide & $\begin{array}{l}-0.0107 \\
(0.0350)\end{array}$ & $\begin{array}{l}-0.00442 \\
(0.0144)\end{array}$ & $\begin{array}{l}0.0151 \\
(0.0494)\end{array}$ & $\begin{array}{l}-0.0214 \\
(0.0307)\end{array}$ & $\begin{array}{l}-0.0115 \\
(0.0172)\end{array}$ & $\begin{array}{l}0.0335 \\
(0.0478)\end{array}$ \\
\hline Pests or livestock disease & $\begin{array}{l}-0.0583^{*} \\
(0.0312)\end{array}$ & $\begin{array}{l}-0.0241^{*} \\
(0.0125)\end{array}$ & $\begin{array}{l}0.0824 * \\
(0.0435)\end{array}$ & $\begin{array}{l}-0.0546 * * \\
(0.0278)\end{array}$ & $\begin{array}{l}-0.0307 * * \\
(0.0147)\end{array}$ & $\begin{array}{l}0.0854 * * \\
(0.042)\end{array}$ \\
\hline Collapse of business & $\begin{array}{l}-0.0645 \\
(0.0896)\end{array}$ & $\begin{array}{l}-0.0266 \\
(0.0366)\end{array}$ & $\begin{array}{l}0.0912 \\
(0.126)\end{array}$ & $\begin{array}{l}-0.0382 \\
(0.073)\end{array}$ & $\begin{array}{l}-0.0179 \\
(0.0407)\end{array}$ & $\begin{array}{l}0.0598 \\
(0.113)\end{array}$ \\
\hline Risk avoidance & $\begin{array}{l}0.119 * * * \\
(0.0208)\end{array}$ & $\begin{array}{l}0.0491 * * * \\
(0.0105)\end{array}$ & $\begin{array}{l}-0.168 * * * \\
(0.0302)\end{array}$ & $\begin{array}{l}0.100 * * * \\
(0.0188)\end{array}$ & $\begin{array}{l}0.0567 * * * \\
(0.012)\end{array}$ & $\begin{array}{l}-0.157 * * * \\
(0.0287)\end{array}$ \\
\hline Risk acceptence & $\begin{array}{l}-0.107 * * \\
(0.0464)\end{array}$ & $\begin{array}{l}-0.0442 * * \\
(0.0194)\end{array}$ & $\begin{array}{l}0.151^{* *} \\
(0.0653)\end{array}$ & $\begin{array}{l}-0.100 * * \\
(0.0409)\end{array}$ & $\begin{array}{l}-0.0538 * * \\
(0.0235)\end{array}$ & $\begin{array}{l}0.157 * * \\
(0.0633)\end{array}$ \\
\hline Access to electricity & $\begin{array}{l}-0.293 * * * \\
(0.0863)\end{array}$ & $\begin{array}{l}-0.121 * * * \\
(0.0367)\end{array}$ & $\begin{array}{l}0.413 * * * \\
(0.121)\end{array}$ & $\begin{array}{l}-0.217 * * * \\
(0.0772)\end{array}$ & $\begin{array}{l}-0.120 * * * \\
(0.0429)\end{array}$ & $\begin{array}{l}0.339 * * * \\
(0.118)\end{array}$ \\
\hline Mountain & $\begin{array}{l}-0.0704 * * * \\
(0.0235)\end{array}$ & $\begin{array}{l}-0.029 * * * \\
(0.0098)\end{array}$ & $\begin{array}{l}0.0994 * * * \\
(0.0329)\end{array}$ & $\begin{array}{l}-0.0635 * * * \\
(0.0207)\end{array}$ & $\begin{array}{l}-0.0359 * * * \\
(0.0116)\end{array}$ & $\begin{array}{l}0.0994 * * * \\
(0.0314)\end{array}$ \\
\hline River & $\begin{array}{l}0.0517 * \\
(0.0284)\end{array}$ & $\begin{array}{l}0.0213^{*} \\
(0.0121)\end{array}$ & $\begin{array}{l}-0.073^{*} \\
(0.0403)\end{array}$ & $\begin{array}{l}0.0460 * \\
(0.0277)\end{array}$ & $\begin{array}{l}0.0252 \\
(0.016)\end{array}$ & $\begin{array}{l}-0.0719^{*} \\
(0.0435)\end{array}$ \\
\hline
\end{tabular}

Note: Model 1 corresponds to regressions with Income and Mean village income. Model 2 corresponds to regressions with Income and Poor (including their interaction). All explanatory variables are exogenous. Significance levels: * $10 \% * *$ $5 \%, * * * 1 \%$. Number of observations: 1198. 
Table 6: Marginal effects, the case of SWB5, Thailand.

\begin{tabular}{|c|c|c|c|c|c|c|}
\hline \multirow[b]{2}{*}{ Variable } & \multicolumn{3}{|c|}{ Model 1} & \multicolumn{3}{|c|}{ Model 2} \\
\hline & $P(S W B 5=1)$ & $P(S W B 5=2)$ & $P(S W B 5=3)$ & $P(S W B 5=1)$ & $P(S W B 5=2)$ & $P(S W B 5=3)$ \\
\hline \multirow[t]{2}{*}{ Income } & $-0.0047 * * *$ & $-0.0015 * * *$ & $0.0063 * * *$ & $-0.0106 * * *$ & $-0.0054 * * *$ & $0.016 * * *$ \\
\hline & $(0.0014)$ & $(0.0005)$ & $(0.0019)$ & $(0.0022)$ & $(0.0016)$ & $(0.0037)$ \\
\hline \multirow[t]{2}{*}{ Mean village income } & -0.0002 & -0.0000 & 0.0003 & -- & -- & -- \\
\hline & $(0.001)$ & $(0.0003)$ & $(0.0014)$ & & & \\
\hline \multirow[t]{2}{*}{ Poor } & -- & -- & -- & 0.0105 & 0.0054 & -0.0159 \\
\hline & & & & $(0.0245)$ & $(0.0125)$ & $(0.037)$ \\
\hline \multirow{2}{*}{$\begin{array}{l}\text { Subjective wealth, wrt village } \\
\text { village }\end{array}$} & -0.0246 & -0.008 & 0.0326 & -0.0145 & -0.0073 & 0.0218 \\
\hline & $(0.0167)$ & $(0.0055)$ & $(0.0221)$ & $(0.0142)$ & $(0.0072)$ & $(0.0213)$ \\
\hline \multirow{2}{*}{$\begin{array}{l}\text { Subjective wealth, wrt country } \\
\text { country }\end{array}$} & $-0.0355 * *$ & $-0.0115 * *$ & $0.047 * *$ & $-0.0291 * *$ & $-0.0148 * *$ & $0.0439 * *$ \\
\hline & $(0.0157)$ & $(0.0051)$ & $(0.0207)$ & $(0.0135)$ & $(0.006785)$ & $(0.020)$ \\
\hline \multirow[t]{2}{*}{ Drought } & $-0.0431 *$ & $-0.0140 *$ & $0.0572 *$ & -0.0301 & -0.0153 & 0.0454 \\
\hline & $(0.0252)$ & $(0.0079)$ & $(0.033)$ & $(0.0216)$ & $(0.0107)$ & $(0.0322)$ \\
\hline \multirow[t]{2}{*}{ Pests or livestock disease } & $-0.136^{* *}$ & $-0.0443 * *$ & $0.181 * *$ & $-0.114 * *$ & $-0.0577 * *$ & $0.172 * *$ \\
\hline & $(0.0548)$ & $(0.0188)$ & $(0.0731)$ & $(0.0465)$ & $(0.0244)$ & $(0.070)$ \\
\hline \multirow[t]{2}{*}{ Collapse of business } & 0.0855 & 0.0278 & -0.113 & 0.0787 & 0.0399 & -0.119 \\
\hline & $(0.0837)$ & $(0.0275)$ & $(0.111)$ & $(0.0706)$ & $(0.0364)$ & $(0.107)$ \\
\hline \multirow[t]{2}{*}{ Risk avoidance } & 0.0252 & 0.0082 & -0.0334 & 0.0174 & 0.0088 & -0.0263 \\
\hline & $(0.0209)$ & $(0.0068)$ & $(0.0277)$ & $(0.0185)$ & $(0.0092)$ & $(0.0276)$ \\
\hline \multirow[t]{2}{*}{ Risk acceptence } & 0.0227 & 0.0073 & -0.030 & 0.0253 & 0.0128 & -0.0381 \\
\hline & $(0.0302)$ & $(0.0099)$ & $(0.040)$ & $(0.0258)$ & $(0.0131)$ & $(0.0388)$ \\
\hline \multirow[t]{2}{*}{ Suffering from serious disease } & -0.0299 & -0.0097 & 0.0396 & -0.0224 & -0.0114 & 0.0337 \\
\hline & $(0.0231)$ & $(0.0075)$ & $(0.0307)$ & $(0.0198)$ & $(0.0101)$ & $(0.0298)$ \\
\hline \multirow[t]{2}{*}{ Average age } & -0.0011 & -0.0003 & 0.0015 & -0.0011 & -0.0005 & 0.0017 \\
\hline & $(0.0009)$ & $(0.0003)$ & $(0.0013)$ & $(0.0008)$ & $(0.0004)$ & $(0.0013)$ \\
\hline \multirow[t]{2}{*}{ Ethnic minority } & 0.0035 & 0.0011 & -0.0047 & -0.0037 & -0.0019 & 0.0056 \\
\hline & $(0.0522)$ & $(0.017)$ & $(0.0692)$ & $(0.0461)$ & $(0.0234)$ & $(0.0694)$ \\
\hline \multirow[t]{2}{*}{ Mountain } & $0.216 * * *$ & $0.0702 * * *$ & $-0.286 * * *$ & $0.169 * * *$ & $0.0855 * * *$ & $-0.254 * * *$ \\
\hline & $(0.0608)$ & $(0.0211)$ & $(0.0808)$ & $(0.0564)$ & $(0.0291)$ & $(0.0839)$ \\
\hline \multirow[t]{2}{*}{ Slope } & -0.006 & -0.0019 & 0.0079 & -0.0022 & -0.0011 & 0.0032 \\
\hline & $(0.0454)$ & $(0.0148)$ & $(0.0602)$ & $(0.0376)$ & $(0.0191)$ & $(0.0567)$ \\
\hline \multirow[t]{2}{*}{ Valley } & $0.151 * * *$ & $0.0492 * * *$ & $-0.200 * * *$ & $0.111 * * *$ & $0.0563 * * *$ & $-0.167 * * *$ \\
\hline & $(0.0247)$ & $(0.0106)$ & $(0.0342)$ & $(0.0224)$ & $(0.0123)$ & $(0.0329)$ \\
\hline
\end{tabular}

Note: Model 1 corresponds to regressions with Income and Mean village income. Model 2 corresponds to regressions with Income and Poor (including their interaction). All explanatory variables are exogenous. Significance levels: * 10\%** 5\%, *** $1 \%$. Number of observations: 1390 . 


\section{Conclusion}

This paper set out to analyze households' subjective well-being using data on rural areas of Vietnam and Thailand. Our findings show that income is one of the key determinants of households' subjective well-being. Moreover, households are sensitive to relative poverty. This finding is not surprising in the case of developing countries and can be interpreted as an income comparison in household preferences. Earning an income lower than the mean village level makes households feel worse off compared to the previous year or the 5 previous years. These results constitute a common point for both countries.

For the rest, there is a significant difference in the impact of other factors such as geographic conditions, wealth effect, environmental risks, etc. In particular, we observed that Thai households are concerned with wealth comparison, while the Vietnamese are not. This implies that for households in 3 rural provinces of Thailand, their wealth is also subject to social comparison. In addition, this comparison may be upward, i.e. households compare their wealth to a wealth level higher than their own.

Environmental risks affect households' well-being differently in the two countries. Moreover, households' attitude to risk acceptance affects their subjective well-being in the Vietnamese case. We found that households that are more willing to accept risk (lower risk aversion) feel better off in the present compared to the previous year or the 5 previous years.

The estimation results show that households' preferences in the two countries are not identical and may be explained by different factors. This paper provides some policy implications for households' happiness, in particular for people in poor and rural areas with a high poverty rate, harsh living conditions and often suffering from environmental risks. The relativeness regarding poverty and wealth means there is a need for policymakers in Vietnam and Thailand to implement measures to reduce poverty and inequality. Moreover, the results on the effects of natural disasters provide some insights into environmental policies in both countries, in particular in terms of prevention policies.

\section{References}

Akay A. and Martinsson P. [2011], Does Relative Income Matter for the Very Poor? Evidence from Rural Ethiopia, Economics Letters, 110, 213-215.

Alpizar F., Carlsson F., Johansson-Stenman O. [2005], How Much Do We Care about Absolute versus Relative Income and Consumption, Revue Économique, 51, 459-471.

Alvarez-Cuadrado, F., Casado J.M., Labeaga J.M. [2015], Envy and Habits: Panel Data Estimates of Interdependent Preferences, Oxford Bulletin of Economics and Statistics, 78(4), 0305-9049 doi: 10.1111/obes.12111.

Arouri M., Nguyen C., Youssef A.B. [2015], Natural Disasters, Household Welfare, and Resilience: Evidence from Rural Vietnam, World Development, 70, 59-77. 
Asadullah M. N., Chaudhury N. [2012], Subjective Well-Being and Relative Poverty in Rural Bangladesh, Journal of Economic Psychology, 33(5), 940-950.

Brekke K.A., Howarth R., [2002]. Status, Growth and the Environment. Edward Elgar, Northampton.

Carlsson F., Johansson-Stenman O., Martisson P. [2007], Do You Enjoy Having More than Others? Survey Evidence of Positional Goods, Economica, 74(296), 586-598.

Clark A.E. [2000], Utilité Absolue ou Utilité Relative, Revue Économique, 51(3), 459-471.

Clark A.E., Oswald A. J. [1996], Satisfaction and Comparison Income, Journal of Public Economics, 61(3), 359-381.

Fafchamps M., Shilpi F. [2008], Subjective Welfare, Isolation, and Relative Consumption, Journal of Development Economics, 86(1), 43-60.

Ferrer-i-Carbonell A., Gowdy J.M. [2007], Environmental Degradation and Happiness, Ecological Economics, 60(3), 509-516.

Hardeweg B. and Waibel, H. (2009), "Collecting Data to Measure Vulnerability to Poverty: an Overview." Paper presented at the Workshop of Research Unit 756 of the Deutsche Forschungsgemeinschaft (DFG).

Hardeweg B., Wagener A., Waibel H. [2010], "Towards Comparative and Aggregate Vulnerability: Analysis of Welfare Distributions in Rural Areas in Thailand and Viet Nam," Paper presented at Jahrestagung des Vereins für Socialpolitik. September 7-10, Kiel, Germany.

Hardeweg B., Wagener A., Waibel H. [2013], A Distributional Approach to Comparing Vulnerability, Applied to Rural Provinces in Thailand and Vietnam, Journal of Asian Economics, 25, 53-65.

Klasen S., Waibel H. [2015], Vulnerability to Poverty in South-East Asia: Drivers, Measurement, Responses, and Policy Issues, World Development, 71, 1-3.

Kurosaki, T. [2014], Vulnerability of Household Consumption to Floods and Droughts in Developing Countries: Evidence from Pakistan, Environmental and Development Economics, 20(2), 209-235.

Limpanonda S. [2012], Provincial Disparities in Thailand: Convergence, Agglomeration Economies and Effects on Poverty, 1988-2008. PhD Thesis. SOAS, University of London.

Ludwig, F., van Scheltinga, C., Verhagen, J., Kruijt, B., Van Ierland, E., Dellink, R., de Bruin K., de Bruin K., Kabat P. [2007], Climate change impacts on developing countries-EU accountability. IP/A/ENVI/ST/2007-04, the European Parliament's Committee on the Environment, Public Health and Food Safety, European Parliament.

Luttmer, E.F. [2005], Neighbors as Negatives: Relative Earnings and Well-Being, Quarterly Journal of Economics, 120(3), 963-1002. 
Markussen T., Fibaek M., Tarp F., Nguyen D.A.T. [2014], Self-Employment and Subjective Well-Being in Rural Vietnam, WIDER Working Paper 2014/108.

Nguyen L. D., Raabe K., Grote U. [2013], Rural-Urban Migration, Household Vulnerability, and Welfare in Vietnam", World Development, 71, 79-93.

Nguyen M.D. [2009], Contribution of Fish Production to Farmers' Subjective Well-Being in Vietnam-a Logistic Model", Journal of the World Aquaculture Society, 40, 417-423.

Nguyen-Van P., Pham T.K.C. [2013], Endogenous Fiscal Policies, Environmental Quality, and Status-Seeking Behavior, Ecological Economics, 88, 32-40.

Norcia M. Rissotto A. [2015], Subjective Perception and Causal Attributions for Poverty in Italy, Journal of Social Sciences, 11, 49-54.

Ravallion, M., Lokshin M. [2010], Who care about relative deprivation?, Journal of Economic Behavior \& Organization 73(2), 171-185.

Rehdanz K., Maddison D. [2008], Local Environmental Quality and Life-Satisfaction in Germany, Ecological Economics, 64(4), 787-797.

Tran T.Q., Nguyen T.Q., Vu V.H., Doan T.T. [2016], Religiosity and Subjective Well-Being among Old People: Evidence from a Transitional Country, Applied Research Quality Life, Springer; International Society for Quality-of-Life Studies, 12(4), 947-962.

Venkatachalam L. [2008], Behavioral economics for environmental policy, Ecological Economics, 67, 640-645.

Wooldridge J. M. [2014], Quasi-Maximum Likelihood Estimation and Testing for Nonlinear Models with Endogenous Explanatory Variables, Journal of Econometrics 182, 226-234.

\section{Appendix}




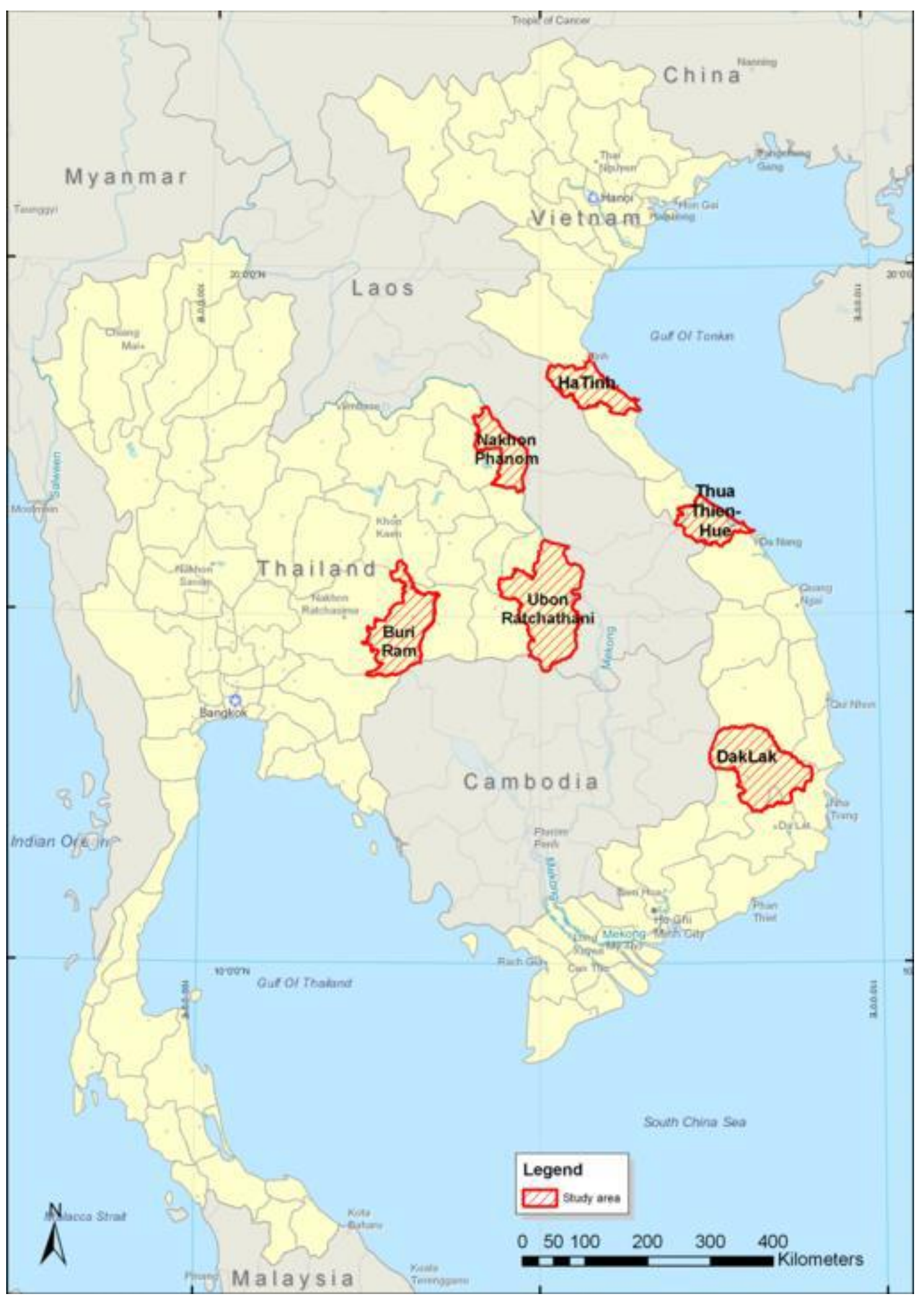

Figure A1: Area of survey. Source: Hardeweg (2009) based on ESRI World Map. 
Table A1: Definition of variables

\begin{tabular}{|c|c|c|}
\hline Variable & Definition & Type \\
\hline$S W B$ & $\begin{array}{l}\text { Household subjective well-being, compared to previous year }(=1 \text { if } \\
\text { much worse/worse, } 2 \text { if same, } 3 \text { if much better/better) }\end{array}$ & Discrete \\
\hline SWB5 & $\begin{array}{l}\text { Household subjective well-being, compared to previous } 5 \text { year ( }=1 \text { if } \\
\text { much worse/worse, } 2 \text { if same, } 3 \text { if much better/better) }\end{array}$ & Discrete \\
\hline Income & Household income, in thousands dollars, PPP & Continuous \\
\hline Mean village income & Mean household income, computed at village level & Continuous \\
\hline Poor & $=1$ if household income lower than the mean village income & Dummy \\
\hline Subjective wealth, wrt village & $\begin{array}{l}\text { Subjective wealth, compared to other village residents (=1 if much } \\
\text { worse/worse, } 2 \text { if same, } 3 \text { if much better/better) }\end{array}$ & Discrete \\
\hline Subjective wealth, wrt country & $\begin{array}{l}\text { Subjective wealth, compared to other countries' residents ( }=1 \text { if much } \\
\text { worse/worse, } 2 \text { if same, } 3 \text { if much better/better) }\end{array}$ & Discrete \\
\hline Suffering from serious disease & $=1$ if serious disease & Dummy \\
\hline Average age & Average age of household members & Continuous \\
\hline Ethnic minority & $\begin{array}{l}\text { Belonging to an ethnic minority ( }=1 \text { if belonging to an ethnic minority, } \\
0 \text { if belonging to Kinh majority group for Vietnam, and if belonging to } \\
\text { Thai ethnic for Thailand) }\end{array}$ & Dummy \\
\hline \multicolumn{3}{|l|}{ Access $t$} \\
\hline Access to electricity & Percentage of village households having access to electricity & Continuous \\
\hline Access to public water supply & Percentage of village households having access to public water supply & Continuous \\
\hline Access to sanitation & Percentage of village households having access to sanitation & Continuous \\
\hline Access to public waste disposal & Percentage of village households having access to public waste disposal & Continuous \\
\hline Access to fixed phone line & Percentage of village households having access to a fixed phone line & Continuous \\
\hline Access to internet & Percentage of village households having access to internet & Continuous \\
\hline \multicolumn{3}{|l|}{ Village characteristics } \\
\hline Travel distance to district town & Travel distance between village and district town & Continuous \\
\hline Mountain & $=1$ if located on a mountain, 0 otherwise & Dummy \\
\hline Slope & $=1$ if located on a slope, 0 otherwise & Dummy \\
\hline Valley & $=1$ if located in a valley, 0 otherwise & Dummy \\
\hline River & $=1$ if located near a river, 0 otherwise & Dummy \\
\hline Lake & $=1$ if located near a lake, 0 otherwise (only Vietnam) & Dummy \\
\hline Coast & $=1$ if located near the coast, 0 otherwise (only Vietnam) & Dummy \\
\hline \multicolumn{3}{|c|}{ 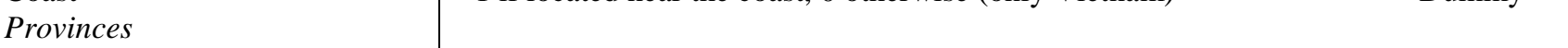 } \\
\hline Ha Tinh & $=1$ if belonging to the province, 0 otherwise (Vietnam) & Dummy \\
\hline Thua Thien - Hue & $=1$ if belonging to the province, 0 otherwise (Vietnam) & Dummy \\
\hline Dak Lak & $=1$ if belonging to the province, 0 otherwise (Vietnam) & Dummy \\
\hline Buriram & $=1$ if belonging to the province, 0 otherwise (Thailand) & Dummy \\
\hline Ubon Ratchathani & $=1$ if belonging to the province, 0 otherwise (Thailand) & Dummy \\
\hline Nakhon Phanom & $=1$ if belonging to the province, 0 otherwise (Thailand) & Dummy \\
\hline
\end{tabular}


Table A2: Descriptive statistics, Vietnam

\begin{tabular}{l|cccc}
\hline Variable & Mean & Std. Dev. & Min & Max \\
\hline SWB & 2.03 & 0.77 & 1 & 3 \\
SWB5 & 2.34 & 0.82 & 1 & 3 \\
Income (thousand dollars) & 5.93 & 5.69 & 0.05 & 45.46 \\
Poor & 0.64 & 0.48 & 0 & 1 \\
Mean village income (thousand dollars PPP) & 6.04 & 2.46 & 1.91 & 17.89 \\
Subjective wealth, wrt village & 1.78 & 0.69 & 1 & 3 \\
Subjective wealth, wrt country & 1.46 & 0.62 & 1 & 3 \\
Drought & 0.07 & 0.26 & 0 & 1 \\
Flooding of land & 0.09 & 0.29 & 0 & 1 \\
Heavy ice rain & 0.04 & 0.20 & 0 & 1 \\
Storm, landslide & 0.10 & 0.30 & 0 & 1 \\
Pests or livestock disease & 0.13 & 0.34 & 0 & 1 \\
Collapse of business & 0.02 & 0.12 & 0 & 1 \\
Average age & 32.66 & 13.58 & 11.6 & 90 \\
Risk avoidance & 0.46 & 0.50 & 0 & 1 \\
Risk neutrality & 0.45 & 0.497 & 0 & 1 \\
Risk acceptance & 0.09 & 0.29 & 0 & 1 \\
Serious disease & 0.37 & 0.48 & 0 & 1 \\
Ethnic minority & 0.17 & 0.38 & 0 & 1 \\
Access to electricity (percentage) & 98.12 & 8.11 & 0 & 100 \\
Access to public water supply (percentage) & 18.99 & 52.3 & 0 & 100 \\
Access to sanitation (percentage) & 45.19 & 37.18 & 0 & 100 \\
Access to public waste disposal (percentage) & 4.10 & 15.98 & 0 & 100 \\
Access to fixed phone line (percentage) & 85.00 & 26.67 & 30 & 100 \\
Access to internet (percentage) & 1.88 & 3.93 & 0 & 20 \\
Travel distance to district town & 13.07 & 10.10 & 0.7 & 70 \\
Slope & 0.29 & 0.46 & 0 & 1 \\
Mountain & 0.47 & 0.50 & 0 & 1 \\
Valley & 0.09 & 0.28 & 0 & 1 \\
River & 0.19 & 0.39 & 0 & 1 \\
Lake & 0.17 & 0.38 & 0 & 1 \\
Coast & 0.05 & 0.22 & 0 & 1 \\
Ha Tinh province & 0.39 & 0.49 & 0 & 1 \\
Thua Thien - Hue province & 0.19 & 0.39 & 0 & 1 \\
Dak Lak province & 0.42 & 0.49 & 0 & 1 \\
\hline & & & & \\
& & & \\
& &
\end{tabular}

Note: number of observations 1198. 
Table A3: Descriptive statistics, Thailand

\begin{tabular}{l|rrrr}
\hline Variable & Mean & Std. Dev. & Min & Max \\
\hline SWB & 2.19 & 0.76 & 1 & 3 \\
SWB5 & 2.31 & 0.82 & 1 & 3 \\
Income (thousand dollars PPP) & 8.32 & 7.80 & 0.04 & 46.58 \\
Poor & 0.63 & 0.48 & 0 & 1 \\
Mean village income (thousand dollars PPP) & 9.22 & 6.32 & 2.01 & 79.16 \\
Subjective wealth, wrt village & 1.92 & 0.58 & 1 & 3 \\
Subjective wealth, wrt country & 1.56 & 0.64 & 1 & 3 \\
Drought & 0.22 & 0.11 & 0 & 1 \\
Flooding of land & 0.09 & 0.28 & 0 & 1 \\
Heavy ice rain & 0.003 & 0.059 & 0 & 1 \\
Storm, landslide & 0.005 & 0.071 & 0 & 1 \\
Pests or livestock disease & 0.04 & 0.20 & 0 & 1 \\
Collapse of business & 0.01 & 0.12 & 0 & 1 \\
Average age & 35.25 & 10.20 & 15.33 & 85 \\
Risk avoidance & 0.28 & 0.45 & 0 & 1 \\
Risk acceptance & 0.12 & 0.33 & 0 & 1 \\
Serious disease & 0.23 & 0.42 & 0 & 1 \\
Ethnic minority & 0.06 & 0.23 & 0 & 1 \\
Access to electricity (in percentage) & 98.79 & 4.13 & 70 & 100 \\
Access to public water supply (in percentage) & 84.47 & 29.25 & 0 & 100 \\
Access to sanitation (in percentage) & 83.57 & 29.06 & 0 & 100 \\
Access to public waste disposal (in percentage) & 15.31 & 35.16 & 0 & 100 \\
Access to fixed phone line (in percentage) & 34.55 & 45.41 & 0 & 100 \\
Access to internet (in percentage) & 2.79 & 10.11 & 0 & 100 \\
Travel distance to district town & 13.38 & 8.42 & 0.1 & 46 \\
Mountain & 0.009 & 0.093 & 0 & 1 \\
Slope & 0.05 & 0.22 & 0 & 1 \\
Valley & 0.004 & 0.066 & 0 & 1 \\
River & 0.18 & 0.39 & 0 & 1 \\
Buriram province & 0.40 & 0.49 & 0 & 1 \\
Ubon Ratchathani province & 0.40 & 0.49 & 0 & 1 \\
Nakhon Phanom province & 0.20 & 0.40 & 0 & 1 \\
\hline & & & &
\end{tabular}

Note: number of observations 1390 
Table A4: Descriptive statistics at province level in Vietnam and Thailand in 2010

\begin{tabular}{|c|c|c|c|c|c|c|c|c|}
\hline & \multicolumn{4}{|c|}{ Vietnam } & \multicolumn{4}{|c|}{ Thailand } \\
\hline & Ha Tinh & $\begin{array}{l}\text { Thua } \\
\text { Thien } \\
\text { Hue }\end{array}$ & Dak Lak & Average & Buriram & $\begin{array}{l}\text { Unbon } \\
\text { Ratchat } \\
\text { hani }\end{array}$ & $\begin{array}{l}\text { Nakhon } \\
\text { Phanom }\end{array}$ & Average \\
\hline$S W B$ & 2.19 & 1.97 & 1.9 & 2.02 & 2.11 & 2.29 & 2.18 & 2.2 \\
\hline SWB5 & 2.43 & 2.17 & 2.32 & 2.34 & 2.23 & 2.38 & 2.32 & 2.3 \\
\hline $\begin{array}{l}\text { Subjective wealth, } \\
\text { wrt village }\end{array}$ & 1.74 & 1.82 & 1.78 & 1.77 & 1.93 & 1.92 & 1.94 & 1.93 \\
\hline $\begin{array}{l}\text { Subjective wealth, } \\
\text { wrt country }\end{array}$ & 1.31 & 1.47 & 1.59 & 1.46 & 1.56 & 1.59 & 1.53 & 1.56 \\
\hline $\begin{array}{l}\text { Income (thousand \$ } \\
\text { PPP) }\end{array}$ & 5.36 & 5.94 & 6.46 & 5.93 & 8.81 & 8.47 & 7.05 & 8.32 \\
\hline $\begin{array}{l}\text { Village Average } \\
\text { Income (thousand \$ } \\
\text { PPP) }\end{array}$ & 5.34 & 6.28 & 6.59 & 6.04 & 10.55 & 8.92 & 7.20 & 9.23 \\
\hline Poor & 0.62 & 0.61 & 0.59 & 0.61 & 0.63 & 0.59 & 0.61 & 0.61 \\
\hline Serious disease & 0.44 & 0.28 & 0.36 & 0.37 & 0.28 & 0.17 & 0.26 & 0.23 \\
\hline Risk avoidance & 0.37 & 0.40 & 0.57 & 0.46 & 0.24 & 0.24 & 0.48 & 0.28 \\
\hline Risk acceptance & 0.11 & 0.10 & 0.07 & 0.09 & 0.13 & 0.14 & 0.09 & 0.13 \\
\hline Risk neutrality & 0.52 & 0.50 & 0.36 & 0.45 & 0.64 & 0.32 & 0.43 & 0.59 \\
\hline Drought & 0.05 & 0.02 & 0.13 & 0.08 & 0.26 & 0.17 & 0.2 & 0.22 \\
\hline Flooding of land & 0.09 & 0.05 & 0.11 & 0.09 & 0.1 & 0.07 & 0.1 & 0.09 \\
\hline Rain & 0.04 & 0.04 & 0.04 & 0.04 & 0.002 & 0.002 & 0.01 & 0.03 \\
\hline Storm, landslide & 0.05 & 0.3 & 0.06 & 0.1 & 0.003 & 0.005 & 0.007 & 0.005 \\
\hline Pest & 0.16 & 0.11 & 0.12 & 0.14 & 0.04 & 0.05 & 0.04 & 0.04 \\
\hline Collapse & 0.01 & 0.02 & 0.01 & 0.01 & 0.01 & 0.02 & 0.01 & 0.01 \\
\hline
\end{tabular}


Table A5: Descriptive statistics at province level in Vietnam and Thailand in 2007.

\begin{tabular}{|c|c|c|c|c|c|c|c|c|}
\hline & \multicolumn{4}{|c|}{ Vietnam } & \multicolumn{4}{|c|}{ Thailand } \\
\hline & $\begin{array}{c}\mathrm{Ha} \\
\text { Tinh }\end{array}$ & $\begin{array}{c}\text { Thua } \\
\text { Thien } \\
\text { Hue }\end{array}$ & $\begin{array}{l}\text { Dak } \\
\text { Lak }\end{array}$ & Average & Buriram & $\begin{array}{c}\text { Unbon } \\
\text { Ratchathani }\end{array}$ & $\begin{array}{l}\text { Nakhon } \\
\text { Phanom }\end{array}$ & Average \\
\hline$S W B$ & 2.19 & 2.27 & 2.41 & 2.3 & 2.09 & 2.1 & 2.01 & 2.08 \\
\hline SWB5 & 2.48 & 2.53 & 2.6 & 2.05 & 2.04 & 2.24 & 2.06 & 2.13 \\
\hline $\begin{array}{l}\text { Subjective wealth, } \\
\text { wrt village }\end{array}$ & 1.68 & 1.70 & 1.69 & 1.69 & 1.75 & 1.80 & 1.81 & 1.78 \\
\hline $\begin{array}{l}\text { Subjective wealth, } \\
\text { wrt country }\end{array}$ & 1.23 & 1.31 & 1.47 & 1.34 & 1.38 & 1.36 & 1.47 & 1.39 \\
\hline Income & 4.82 & 4.23 & 9.56 & 6.52 & 8.83 & 8.15 & 13.17 & 9.44 \\
\hline $\begin{array}{l}\text { Village average } \\
\text { income }\end{array}$ & 4.72 & 4.28 & 9.18 & 6.42 & 8.95 & 8.00 & 13.05 & 9.38 \\
\hline Poor & 0.54 & 0.53 & 0.48 & 0.51 & 0.59 & 0.56 & 0.6 & 0.58 \\
\hline Serious disease & 0.27 & 0.32 & 0.50 & 0.37 & 0.22 & 0.29 & 0.25 & 0.25 \\
\hline Drought & 0.05 & 0.04 & 0.34 & 0.16 & 0.35 & 0.24 & 0.26 & 0.28 \\
\hline Flooding of land & 0.13 & 0.2 & 0.07 & 0.12 & 0.11 & 0.09 & 0.21 & 0.12 \\
\hline Rain & 0.12 & 0.18 & 0.01 & 0.09 & 0.004 & 0.031 & 0.018 & 0.017 \\
\hline Storm, landslide & 0.002 & 0.034 & 0 & 0.008 & 0 & 0.002 & 0 & 0.01 \\
\hline Pest & 0.17 & 0.12 & 0.15 & 0.15 & 0.03 & 0.11 & 0.02 & 0.06 \\
\hline Collapse & 0.015 & 0 & 0.008 & 0.009 & 0.04 & 0.03 & 0.03 & 0.03 \\
\hline
\end{tabular}

Note: Information about risk attitude is not available for 2007. 
Table A6: Distribution of Subjective wealth compared to the previous year and subjective wealth compared to the 5 previous years, Vietnam.

\begin{tabular}{|l|cccc|r|}
\hline \multirow{2}{*}{$\begin{array}{c}\text { Subjective wealth } \\
\text { compared to the village }\end{array}$} & \multicolumn{2}{|c|}{ Subjective wealth compared to country } & \multirow{2}{*}{ Total } \\
\cline { 2 - 6 } & Worse/much worse & Same & Better/much better & 445 \\
Worse/much worse & 431 & 12 & 2 & 576 \\
Same & 251 & 315 & 10 & 177 \\
Better/much better & 47 & 59 & 71 & 1198 \\
\hline Total & 729 & 386 & 83 & . \\
\hline
\end{tabular}

Table A7: Distribution of Subjective wealth compared to the previous year and subjective wealth compared to the 5 previous years, Thailand

\begin{tabular}{|l|cccc|r|}
\hline \multirow{2}{*}{$\begin{array}{c}\text { Subjective wealth } \\
\text { compared to the village }\end{array}$} & \multicolumn{2}{|c|}{ Subjective wealth compared to country } & \\
\cline { 2 - 5 } & Worse/much worse & Same & Better/much better & Total \\
\hline Worse/much worse & 234 & 39 & 16 & 289 \\
Same as & 435 & 439 & 41 & 915 \\
Better/Much better & 50 & 79 & 57 & 186 \\
\hline Total & 719 & 557 & 114 & 1390 \\
\hline
\end{tabular}

Table A8: Likelihood-ratio test (H0: standard ordered probit model vs $\mathrm{H} 1$ : ordered probit model with unobserved heterogeneity $v_{i}$ )

\begin{tabular}{lcccc}
\hline & \multicolumn{2}{c}{ Vietnam } & \multicolumn{2}{c}{ Thailand } \\
\cline { 2 - 5 } & SWB & SWB5 & SWB & SWB5 \\
\hline Model 1 (with mean village income) & 2.073 & 0.309 & 0.959 & 2.259 \\
Model 2 (with Poor) & 1.946 & 0.387 & 1.354 & 3.238 \\
\hline
\end{tabular}


Table A9: Robust t-statistics of regressor exogeneity test (variable addition test)

\begin{tabular}{lcccc|cccc}
\hline & \multicolumn{3}{c|}{ Vietnam } & \multicolumn{4}{c}{ Thailand } \\
\cline { 2 - 8 } & \multicolumn{2}{c}{ Model 1 } & \multicolumn{2}{c}{ Model 2 } & \multicolumn{2}{c}{ Model 1 } & \multicolumn{2}{c}{ Model 2 } \\
\cline { 2 - 9 } Variable & SWB & SWB5 & SWB & SWB5 & SWB & SWB5 & SWB & SWB5 \\
\hline Income & 1.26 & -0.24 & 1.31 & 1.23 & -0.94 & -0.07 & -1.04 & -0.90 \\
Poor & -- & -- & 1.10 & $2.05^{* *}$ & -- & -- & -0.14 & -0.71 \\
Poor*Income & -- & -- & -0.99 & 0.01 & -- & -- & -1.62 & -0.66 \\
Risk avoidance & 1.10 & -1.22 & 0.91 & -1.37 & 0.39 & -0.55 & 0.45 & -0.38 \\
Risk acceptance & 0.57 & -1.09 & 0.17 & -1.44 & 1.48 & 0.28 & $1.77 *$ & 0.57 \\
\hline
\end{tabular}

Notes. Significance levels: $* 10 \%, * * 5 \%$. 
Table A10: Estimation results for $S W B$.

\begin{tabular}{|c|c|c|c|c|c|c|c|c|}
\hline \multirow[b]{3}{*}{ Variable } & \multicolumn{4}{|c|}{ Vietnam } & \multicolumn{4}{|c|}{ Thailand } \\
\hline & \multirow{2}{*}{$\begin{array}{l}\text { Model } 1 \\
\text { Coef. }\end{array}$} & \multicolumn{3}{|c|}{ Model 2} & \multicolumn{2}{|c|}{ Model 1} & \multicolumn{2}{|c|}{ Model 2} \\
\hline & & Std.Err. & Coef. & Std.Err. & Coef. & Std.Err. & Coef. & Std.Err. \\
\hline Income & $0.023 * * * *$ & 0.007 & 0.0073 & 0.009 & $0.014 * * *$ & 0.005 & 0.004 & 0.006 \\
\hline Mean village income & -0.0028 & 0.015 & -- & -- & 0.003 & 0.004 & -- & -- \\
\hline Poor & -- & -- & $-.4203 * * *$ & 0.122 & -- & -- & $-0.350 * * *$ & 0.127 \\
\hline Poor=1\#Income & -- & -- & $0.0672 * * *$ & 0.019 & & & $0.044 * * *$ & 0.015 \\
\hline $\begin{array}{l}\text { Subjective wealth, wrt } \\
\text { village }\end{array}$ & -0.0377 & 0.060 & -0.0597 & 0.060 & -0.007 & 0.056 & -0.021 & 0.056 \\
\hline $\begin{array}{l}\text { Subjective wealth, wrt } \\
\text { country }\end{array}$ & 0.1018 & 0.071 & 0.0887 & 0.072 & $0.138 * *$ & 0.054 & $0.136^{* *}$ & 0.054 \\
\hline Drought & $0.2110^{*}$ & 0.118 & $0.2301 *$ & 0.118 & $0.203^{* *}$ & 0.081 & $0.186^{* *}$ & 0.081 \\
\hline Flooding & $0.309 * * *$ & 0.109 & $0.2943 * * *$ & 0.111 & -0.019 & 0.108 & -0.028 & 0.108 \\
\hline Heavy ice rain & $0.3229 * *$ & 0.161 & $0.2968 *$ & 0.162 & -- & -- & -- & -- \\
\hline Storm, landslide & -0.1678 & 0.123 & -0.1410 & 0.125 & 0.382 & 0.328 & 0.387 & 0.339 \\
\hline Pests or livestock disease & $0.1511 *$ & 0.090 & $0.1579 *$ & 0.090 & 0.215 & 0.152 & 0.205 & 0.149 \\
\hline Collapse of business & 0.1945 & 0.296 & 0.1432 & 0.280 & -0.135 & 0.267 & -0.144 & 0.269 \\
\hline Risk avoidance & $-0.314 * * *$ & 0.067 & $-0.3011 * * *$ & 0.067 & -0.094 & 0.067 & -0.085 & 0.069 \\
\hline Risk acceptance & $0.552 * * *$ & 0.117 & $0.5682 * * *$ & 0.119 & 0.071 & 0.092 & 0.062 & 0.091 \\
\hline Serious disease & $-0.1166^{*}$ & 0.063 & $-0.1202 *$ & 0.063 & 0.035 & 0.077 & 0.026 & 0.077 \\
\hline Average age & 0.0015 & 0.002 & 0.0016 & 0.002 & 0.004 & 0.003 & 0.004 & 0.003 \\
\hline Ethnic minority & 0.1102 & 0.104 & 0.0988 & 0.105 & 0.144 & 0.170 & 0.156 & 0.173 \\
\hline Access to electricity & $0.808 * * *$ & 0.226 & $0.751 * * *$ & 0.228 & -0.982 & 0.654 & -0.917 & 0.668 \\
\hline $\begin{array}{l}\text { Access to public water } \\
\text { supply }\end{array}$ & -0.0214 & 0.094 & -0.0370 & 0.095 & $-0.159 *$ & 0.092 & $-0.172 *$ & 0.090 \\
\hline Access to sanitation & 0.0607 & 0.147 & 0.0336 & 0.147 & 0.055 & 0.145 & 0.067 & 0.144 \\
\hline $\begin{array}{l}\text { Access to public waste } \\
\text { disposal }\end{array}$ & -0.2393 & 0.255 & -0.2250 & 0.254 & 0.053 & 0.092 & 0.056 & 0.094 \\
\hline Access to fixed phone line & -0.0971 & 0.165 & -0.1003 & 0.171 & -0.026 & 0.096 & -0.029 & 0.098 \\
\hline Access to internet & 1.1243 & 0.987 & 1.0266 & 0.976 & 0.163 & 0.307 & 0.195 & 0.341 \\
\hline $\begin{array}{l}\text { Travel distance to district } \\
\text { town }\end{array}$ & 0.0032 & 0.004 & 0.0028 & 0.004 & 0.001 & 0.004 & 0.001 & 0.004 \\
\hline Mountain & $0.1967 * *$ & 0.080 & $0.1975 * *$ & 0.081 & $-0.789 * * *$ & 0.109 & $-0.766^{* * * *}$ & 0.119 \\
\hline Slope & -0.1097 & 0.109 & -0.0804 & 0.109 & -0.126 & 0.135 & -0.129 & 0.136 \\
\hline Valley & 0.1819 & 0.147 & 0.1749 & 0.150 & $-0.421 * * *$ & 0.083 & $-0.378 * * *$ & 0.082 \\
\hline River & -0.0393 & 0.117 & -0.0359 & 0.120 & $0.154^{*}$ & 0.083 & $0.145^{*}$ & 0.085 \\
\hline Lake & -0.0148 & 0.099 & -0.0213 & 0.098 & -- & -- & -- & -- \\
\hline Coast & -0.0795 & 0.126 & -0.0752 & 0.124 & -- & -- & -- & -- \\
\hline Ha Tinh & $0.425 * * *$ & 0.118 & $0.4626 * * *$ & 0.123 & -- & -- & -- & -- \\
\hline Thua Thien-Hue & 0.2006 & 0.147 & 0.2311 & 0.145 & -- & -- & -- & -- \\
\hline Buriram & -- & -- & -- & -- & -0.111 & 0.119 & -0.119 & 0.119 \\
\hline Ubon Ratchathani & -- & -- & - & -- & $0.231^{* *}$ & 0.111 & $0.229 * *$ & 0.113 \\
\hline$c_{1}$ & $0.6134 *$ & 0.322 & 0.2938 & 0.340 & $-1.288^{*}$ & 0.673 & $-1.456 * *$ & 0.690 \\
\hline$c_{2}$ & $1.791 * * *$ & 0.323 & $1.478 * * *$ & 0.341 & -0.207 & 0.675 & -0.370 & 0.691 \\
\hline Log-likelihood & -1223.13 & & -1217.63 & & -1442.99 & & -1438.04 & \\
\hline Number of observations & 1201 & & 1201 & & 1390 & & 1390 & \\
\hline
\end{tabular}

Note: Model 1 corresponds to regressions with Income and Mean village income. Model 2 corresponds to regressions with Poor. All explanatory variables are exogenous based on variable addition test (Wooldridge, 2014). Significance levels: *10\%, $* * 5 \%, * * * 1 \%$. 
Table A11: Estimation results for SWB5.

\begin{tabular}{|c|c|c|c|c|c|c|c|c|}
\hline \multirow[b]{3}{*}{ Variable } & \multicolumn{4}{|c|}{ Vietnam } & \multicolumn{4}{|c|}{ Thailand } \\
\hline & \multicolumn{2}{|c|}{ Model 1} & \multicolumn{2}{|c|}{ Model 2} & \multicolumn{2}{|c|}{ Model 1} & \multicolumn{2}{|c|}{ Model 2} \\
\hline & Coef. & Std.Err. & Coef. & Std.Err. & Coef. & Std.Err. & Coef. & Std.Err \\
\hline Income & $0.0423 * * *$ & 0.008 & 0.005 & 0.009 & $0.016 * * *$ & 0.005 & -0.004 & 0.006 \\
\hline Mean village income & $-0.035^{*}$ & 0.018 & -- & -- & 0.001 & 0.003 & -- & -- \\
\hline Poor & -- & -- & $-0.699 * * *$ & 0.153 & -- & -- & $-0.650 * * *$ & 0.137 \\
\hline Poor=1\#Income & -- & -- & $0.075^{* * *}$ & 0.025 & -- & -- & $0.073 * * *$ & 0.017 \\
\hline $\begin{array}{l}\text { Subjective wealth } \\
\text { wrt village }\end{array}$ & 0.011 & 0.068 & -0.021 & 0.065 & 0.082 & 0.055 & 0.057 & 0.055 \\
\hline $\begin{array}{l}\text { Subjective wealth wrt } \\
\text { country }\end{array}$ & 0.030 & 0.076 & -0.001 & 0.075 & $0.118^{* *}$ & 0.052 & $0.114 * *$ & 0.052 \\
\hline Drought & 0.078 & 0.135 & 0.110 & 0.136 & $0.144^{*}$ & 0.083 & 0.119 & 0.084 \\
\hline Flooding & $0.477 * * *$ & 0.128 & $0.472 * * *$ & 0.128 & 0.094 & 0.107 & 0.081 & 0.108 \\
\hline Heavy ice rain & $0.584 * * *$ & 0.199 & $0.541 * * *$ & 0.207 & -- & -- & -- & -- \\
\hline Storm, landslide & 0.038 & 0.126 & 0.088 & 0.126 & 0.259 & 0.407 & 0.304 & 0.389 \\
\hline $\begin{array}{l}\text { Pests or livestock } \\
\text { disease }\end{array}$ & $0.210^{*}$ & 0.111 & $0.226 * *$ & 0.110 & $0.455 * *$ & 0.184 & $0.447 * *$ & 0.182 \\
\hline Collapse of business & 0.232 & 0.321 & 0.158 & 0.298 & -0.285 & 0.280 & -0.309 & 0.278 \\
\hline Risk avoidance & $-0.428 * * *$ & 0.077 & $-0.415 * * *$ & 0.075 & -0.084 & 0.069 & -0.068 & 0.072 \\
\hline Risk acceptance & $0.385 * *$ & 0.167 & $0.414 * *$ & 0.167 & -0.076 & 0.101 & -0.099 & 0.101 \\
\hline Serious disease & -0.014 & 0.078 & -0.011 & 0.077 & 0.100 & 0.077 & 0.088 & 0.078 \\
\hline Average age & 0.002 & 0.003 & 0.002 & 0.002 & 0.004 & 0.003 & 0.004 & 0.003 \\
\hline Ethnic minority & -0.165 & 0.103 & $-0.192 *$ & 0.105 & -0.012 & 0.174 & 0.014 & 0.181 \\
\hline Access to electricity & $1.053 * * *$ & 0.308 & $0.895 * * *$ & 0.308 & -1.012 & 0.978 & -0.901 & 0.974 \\
\hline $\begin{array}{l}\text { Access to public } \\
\text { water supply }\end{array}$ & -0.066 & 0.110 & -0.069 & 0.114 & -0.210 & 0.132 & $-0.229 *$ & 0.131 \\
\hline Access to sanitation & 0.0408 & 0.142 & -0.007 & 0.140 & 0.139 & 0.170 & 0.164 & 0.170 \\
\hline $\begin{array}{l}\text { Access to public } \\
\text { waste disposal }\end{array}$ & -0.126 & 0.287 & -0.086 & 0.296 & 0.057 & 0.098 & 0.068 & 0.101 \\
\hline $\begin{array}{l}\text { Access to fixed phone } \\
\text { line }\end{array}$ & -0.132 & 0.173 & -0.162 & 0.187 & 0.002 & 0.137 & -0.000 & 0.140 \\
\hline Access to internet & 0.396 & 0.934 & 0.117 & 0.942 & -0.278 & 0.216 & -0.255 & 0.259 \\
\hline $\begin{array}{l}\text { Travel distance to } \\
\text { district town }\end{array}$ & -0.003 & 0.003 & -0.004 & 0.003 & 0.001 & 0.004 & 0.0013 & 0.005 \\
\hline Mountain & $0.253 * * *$ & 0.084 & $0.262 * * *$ & 0.083 & $-0.720 * * *$ & 0.204 & $-0.663 * * *$ & 0.219 \\
\hline Slope & -0.155 & 0.105 & -0.092 & 0.105 & 0.020 & 0.152 & 0.008 & 0.148 \\
\hline Valley & 0.074 & 0.131 & 0.070 & 0.135 & $-0.505 * * *$ & 0.087 & $-0.436 * * *$ & 0.086 \\
\hline River & $-0.186^{*}$ & 0.103 & $-0.190 *$ & 0.114 & 0.099 & 0.104 & 0.087 & 0.108 \\
\hline Lake & -0.017 & 0.098 & -0.017 & 0.096 & -- & -- & -- & -- \\
\hline Coast & 0.156 & 0.167 & 0.172 & 0.169 & -- & -- & -- & -- \\
\hline Ha Tinh & -0.111 & 0.131 & -0.020 & 0.124 & -- & -- & -- & -- \\
\hline Thua Thien-Hue & -0.237 & 0.154 & -0.191 & 0.159 & -- & -- & -- & -- \\
\hline Buriram & -- & -- & -- & -- & -0.182 & 0.111 & $-0.199 *$ & 0.115 \\
\hline Ubon Ratchathani & -- & -- & -- & -- & 0.119 & 0.118 & 0.116 & 0.118 \\
\hline$c_{1}$ & 0.066 & 0.387 & -0.476 & 0.424 & -1.157 & 0.990 & -1.476 & 0.985 \\
\hline$c_{2}$ & $0.736^{*}$ & 0.385 & 0.201 & 0.419 & -0.499 & 0.990 & -0.809 & 0.985 \\
\hline Log-likelihood & -1095.99 & & -1087.13 & & -1372.24 & & -1358.16 & \\
\hline \#observations & 1198 & & 1198 & & 1390 & & 1390 & \\
\hline
\end{tabular}

Note: Model 1 corresponds to regressions with Income and Mean village income. Model 2 corresponds to regressions with Poor. All explanatory variables are exogenous based on variable addition test (Wooldridge, 2014). Significance levels: *10\%, $* * 5 \%, * * * 1 \%$. 
Table A12: First-step estimation for Income.

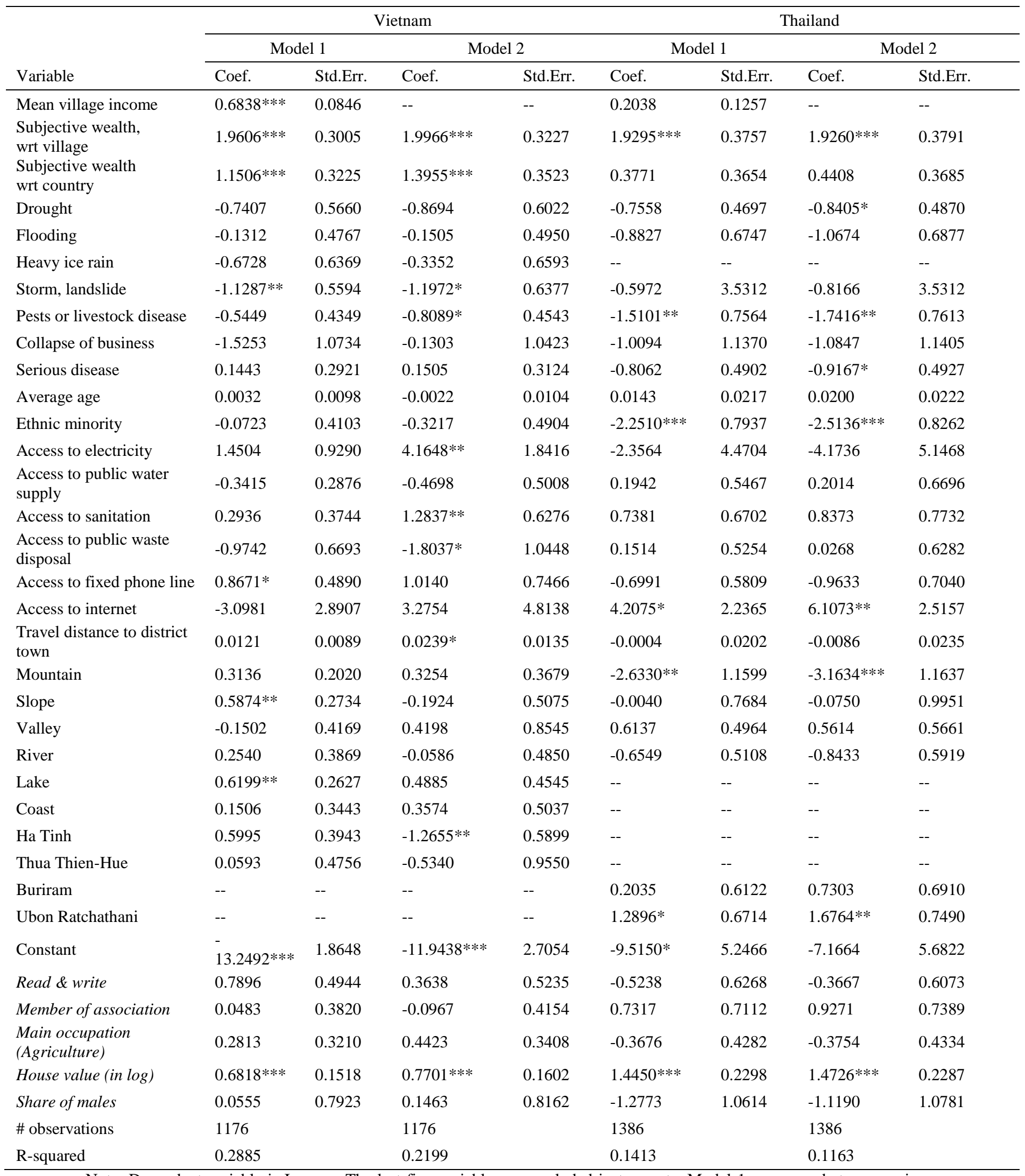

Note: Dependent variable is Income. The last five variables are excluded instruments. Model 1 corresponds to regressions with Income and Mean village income. Model 2 corresponds to regressions with Poor. Significance levels: *10\%, ** 5\%, *** $1 \%$. 
Table A13: First-step estimation for Risk_Avoidance.

\begin{tabular}{|c|c|c|c|c|c|c|c|c|}
\hline \multirow[b]{3}{*}{ Variable } & \multicolumn{4}{|c|}{ Vietnam } & \multicolumn{4}{|c|}{ Thailand } \\
\hline & \multicolumn{2}{|c|}{ Model 1} & \multicolumn{2}{|c|}{ Model 2} & \multicolumn{2}{|c|}{ Model 1} & \multicolumn{2}{|c|}{ Model 2} \\
\hline & Coef. & Std.Err. & Coef. & Std.Err. & Coef. & Std.Err. & Coef. & Std.Err \\
\hline Mean village income & 0.0072 & 0.0191 & -- & -- & -0.0063 & 0.0070 & -- & -- \\
\hline $\begin{array}{l}\text { Subjective wealth, wrt } \\
\text { village }\end{array}$ & $-.2567 * * *$ & 0.0728 & $-0.2563 * * *$ & 0.0727 & -0.0927 & 0.0760 & -0.0935 & 0.0761 \\
\hline $\begin{array}{l}\text { Subjective wealth, wrt } \\
\text { country }\end{array}$ & $-.2394 * * *$ & 0.0813 & $-0.2367 * * *$ & 0.0814 & -0.0749 & 0.0683 & -0.0779 & 0.0682 \\
\hline Drought & $-0.2914 *$ & 0.1582 & $-0.2925^{*}$ & 0.1584 & $0.2112 * *$ & 0.0881 & $0.2128 * *$ & 0.0877 \\
\hline Flooding & -0.1141 & 0.1401 & -0.1140 & 0.1399 & -0.0976 & 0.1313 & -0.0931 & 0.1312 \\
\hline Heavy ice rain & -0.1578 & 0.1768 & -0.1539 & 0.1763 & -- & -- & -- & -- \\
\hline Storm, landslide & -0.0278 & 0.1479 & -0.0286 & 0.1479 & 0.3295 & 0.5196 & 0.3355 & 0.5195 \\
\hline Pests or livestock disease & 0.0554 & 0.1156 & 0.0529 & 0.1157 & $-0.4086^{* *}$ & 0.1970 & $-0.4040 * *$ & 0.1974 \\
\hline Collapse of business & 0.0021 & 0.3229 & 0.0180 & 0.3281 & -0.1750 & 0.3449 & -0.1745 & 0.3449 \\
\hline Serious disease & 0.0936 & 0.0773 & 0.0938 & 0.0773 & -0.0548 & 0.0900 & -0.0516 & 0.0898 \\
\hline Average age & -0.0030 & 0.0032 & -0.0031 & 0.0032 & 0.0031 & 0.0035 & 0.0029 & 0.0035 \\
\hline Ethnic minority & -0.0002 & 0.1301 & -0.0025 & 0.1304 & 0.0800 & 0.1480 & 0.0882 & 0.1486 \\
\hline Access to electricity & $0.6457 *$ & 0.3626 & $0.6734 * *$ & 0.3429 & -0.1828 & 0.8646 & -0.1374 & 0.8762 \\
\hline $\begin{array}{l}\text { Access to public water } \\
\text { supply }\end{array}$ & 0.0530 & 0.0895 & 0.0517 & 0.0900 & -0.0740 & 0.1457 & -0.0747 & 0.1472 \\
\hline Access to sanitation & -0.1288 & 0.1670 & -0.1183 & 0.1673 & 0.2108 & 0.1829 & 0.2085 & 0.1828 \\
\hline $\begin{array}{l}\text { Access to public waste } \\
\text { disposal }\end{array}$ & -0.1340 & 0.2613 & -0.1427 & 0.2612 & 0.1378 & 0.1088 & 0.1408 & 0.1106 \\
\hline $\begin{array}{l}\text { Access to fixed phone } \\
\text { line }\end{array}$ & 0.0515 & 0.1688 & 0.0526 & 0.1709 & $-0.4999 * * *$ & 0.1276 & $-0.4922 * * *$ & 0.1282 \\
\hline Access to internet & 0.5240 & 1.1313 & 0.5893 & 1.0809 & -0.0758 & 0.3513 & -0.1336 & 0.3460 \\
\hline $\begin{array}{l}\text { Travel distance to } \\
\text { district town }\end{array}$ & 0.0035 & 0.0043 & 0.0036 & 0.0043 & 0.0001 & 0.0050 & 0.0003 & 0.0051 \\
\hline Mountain & -0.0196 & 0.0890 & -0.0195 & 0.0886 & -0.0611 & 0.1274 & -0.0465 & 0.1255 \\
\hline Slope & 0.1161 & 0.1279 & 0.1081 & 0.1242 & -0.0301 & 0.1303 & -0.0293 & 0.1332 \\
\hline Valley & -0.0640 & 0.1769 & -0.0586 & 0.1741 & 0.1076 & 0.1135 & 0.1088 & 0.1141 \\
\hline River & 0.0420 & 0.1220 & 0.0387 & 0.1239 & 0.1784 & 0.1130 & 0.1837 & 0.1123 \\
\hline Lake & -0.1232 & 0.1232 & -0.1248 & 0.1234 & -- & -- & -- & -- \\
\hline Coast & 0.1227 & 0.1079 & 0.1248 & 0.1086 & -- & -- & -- & -- \\
\hline Ha Tinh & $-0.5554 * * *$ & 0.1651 & $-0.5750 * * *$ & 0.1663 & -- & -- & -- & -- \\
\hline Thua Thien-Hue & $-0.4029 * *$ & 0.1574 & $-0.4088 * * *$ & 0.1585 & -- & -- & -- & -- \\
\hline Buriram & -- & -- & -- & -- & $-0.6748 * * *$ & 0.1167 & $-0.6899 * * *$ & 0.1151 \\
\hline Ubon Ratchathani & -- & -- & -- & -- & $-0.2427 *$ & 0.1442 & $-0.2539 *$ & 0.1434 \\
\hline Constant & $1.4534 * * *$ & 0.5597 & $1.4673^{* * *}$ & 0.5600 & -0.4205 & 1.0497 & -0.4813 & 1.0522 \\
\hline Read \& write & -0.0457 & 0.1332 & -0.0495 & 0.1318 & -0.2022 & 0.1585 & -0.2073 & 0.1577 \\
\hline Member of association & 0.0649 & 0.0903 & 0.0630 & 0.0904 & 0.0844 & 0.1641 & 0.0797 & 0.1636 \\
\hline $\begin{array}{l}\text { Main occupation } \\
\text { (Agriculture) }\end{array}$ & -0.0375 & 0.0832 & -0.0357 & 0.0830 & -0.0769 & 0.0897 & -0.0761 & 0.0898 \\
\hline House value (in log) & $-0.1387 * * *$ & 0.0379 & $-0.1379 * * *$ & 0.0376 & $0.0875 * *$ & 0.0394 & $0.0866 * *$ & 0.0393 \\
\hline Share of males & 0.1706 & 0.2175 & 0.1722 & 0.2182 & -0.1580 & 0.2136 & -0.1602 & 0.2140 \\
\hline \# observations & 1175 & & 1175 & & 1384 & & 1384 & \\
\hline Log-likelihood & -730.3648 & & -730.4475 & & -766.6347 & & -767.095 & \\
\hline
\end{tabular}

Note: Dependent variable is Risk_Avoidance. The last five variables are excluded instruments. Model 1 corresponds to regressions with Income and Mean village income. Model 2 corresponds to regressions with Poor. Significance levels: *10\%, $* * 5 \%, * * * 1 \%$. 
Table A14: First-step estimation for Risk_Acceptance.

\begin{tabular}{|c|c|c|c|c|c|c|c|c|}
\hline \multirow[b]{3}{*}{ Variable } & \multicolumn{4}{|c|}{ Vietnam } & \multicolumn{4}{|c|}{ Thailand } \\
\hline & \multicolumn{2}{|c|}{ Model 1} & \multicolumn{2}{|c|}{ Model 2} & \multicolumn{2}{|c|}{ Model 1} & \multicolumn{2}{|c|}{ Model 2} \\
\hline & Coef. & Std.Err. & Coef. & Std.Err. & Coef. & Std.Err. & Coef. & Std.Err \\
\hline Mean village income & 0.0172 & 0.0224 & -- & -- & $0.0098 * *$ & 0.0040 & -- & -- \\
\hline $\begin{array}{l}\text { Subjective wealth, wrt } \\
\text { village }\end{array}$ & $0.2398 * *$ & 0.0991 & $0.2391 * *$ & 0.0984 & 0.0514 & 0.0787 & 0.0494 & 0.0789 \\
\hline $\begin{array}{l}\text { Subjective wealth, } \\
\text { wrt country }\end{array}$ & 0.1373 & 0.1000 & 0.1429 & 0.0984 & -0.0938 & 0.0823 & -0.0919 & 0.0820 \\
\hline Drought & -0.2122 & 0.2422 & -0.2125 & 0.2417 & -0.0414 & 0.1102 & -0.0491 & 0.1103 \\
\hline Flooding & 0.0966 & 0.1941 & 0.0946 & 0.1942 & 0.0087 & 0.1541 & -0.0019 & 0.1533 \\
\hline Heavy ice rain & 0.2606 & 0.2813 & 0.2668 & 0.2812 & -- & -- & -- & -- \\
\hline Storm, landslide & -0.1217 & 0.1975 & -0.1222 & 0.1973 & 0.2458 & 0.6378 & 0.2290 & 0.6390 \\
\hline $\begin{array}{l}\text { Pests or livestock } \\
\text { disease }\end{array}$ & -0.0825 & 0.1909 & -0.0902 & 0.1906 & $-0.6645^{* *}$ & 0.3253 & $-0.6716^{* *}$ & 0.3259 \\
\hline Collapse of business & -0.1577 & 0.4082 & -0.1170 & 0.3969 & 0.1052 & 0.3368 & 0.0970 & 0.3361 \\
\hline Serious disease & -0.0524 & 0.1172 & -0.0500 & 0.1173 & -0.0001 & 0.1101 & -0.0078 & 0.1098 \\
\hline Average age & 0.0030 & 0.0042 & 0.0028 & 0.0041 & $-0.0102 * *$ & 0.0042 & $-0.0099 * *$ & 0.0042 \\
\hline Ethnic minority & -0.0947 & 0.2232 & -0.0963 & 0.2230 & -0.1973 & 0.2428 & -0.2067 & 0.2436 \\
\hline Access to electricity & $-0.9143^{* * *}$ & 0.3457 & $-0.8665 * *$ & 0.3384 & -0.7690 & 0.6947 & -0.8549 & 0.6830 \\
\hline $\begin{array}{l}\text { Access to public water } \\
\text { supply }\end{array}$ & -0.0727 & 0.1452 & -0.0726 & 0.1450 & -0.0215 & 0.1624 & -0.0206 & 0.1614 \\
\hline Access to sanitation & -0.0389 & 0.2249 & -0.0153 & 0.2255 & -0.2645 & 0.1679 & -0.2620 & 0.1659 \\
\hline $\begin{array}{l}\text { Access to public waste } \\
\text { disposal }\end{array}$ & 0.0302 & 0.2894 & 0.0077 & 0.2898 & $0.1968 *$ & 0.1157 & 0.1891 & 0.1162 \\
\hline $\begin{array}{l}\text { Access to fixed phone } \\
\text { line }\end{array}$ & 0.2195 & 0.2481 & 0.2139 & 0.2475 & $0.3786 * * *$ & 0.1458 & $0.3607 * *$ & 0.1446 \\
\hline Access to internet & 0.9612 & 1.2255 & 1.0826 & 1.2303 & $-1.1285^{* *}$ & 0.4787 & $-0.9784 * *$ & 0.4609 \\
\hline $\begin{array}{l}\text { Travel distance to } \\
\text { district town }\end{array}$ & $-0.0147^{* *}$ & 0.0074 & $-0.0138 *$ & 0.0073 & 0.0010 & 0.0048 & 0.0006 & 0.0047 \\
\hline Mountain & -0.1697 & 0.1241 & -0.1701 & 0.1243 & 0.1733 & 0.2571 & 0.1477 & 0.2567 \\
\hline Slope & 0.0698 & 0.1834 & 0.0534 & 0.1831 & 0.0722 & 0.2116 & 0.0673 & 0.2049 \\
\hline Valley & $0.5117 * *$ & 0.2123 & $0.5214 * *$ & 0.2094 & $0.3071 * *$ & 0.1198 & $0.3011 * *$ & 0.1183 \\
\hline River & -0.2039 & 0.1820 & -0.2148 & 0.1797 & -0.0336 & 0.1166 & -0.0462 & 0.1162 \\
\hline Lake & -0.2107 & 0.1832 & -0.2188 & 0.1807 & -- & -- & -- & -- \\
\hline Coast & -0.0356 & 0.2169 & -0.0355 & 0.2149 & -- & -- & -- & -- \\
\hline Ha Tinh & $0.4504 * *$ & 0.2266 & $0.4058 *$ & 0.2191 & -- & -- & -- & -- \\
\hline Thua Thien-Hue & $0.4486 * *$ & 0.2097 & $0.4356 * *$ & 0.2090 & -- & -- & -- & -- \\
\hline Buriram & -- & -- & -- & -- & 0.1930 & 0.1259 & $0.2206^{*}$ & 0.1254 \\
\hline Ubon Ratchathani & -- & -- & -- & -- & 0.0005 & 0.1351 & 0.0199 & 0.1357 \\
\hline Constant & $-1.8554 * * *$ & 0.6632 & $-1.8035 * * *$ & 0.6611 & -0.4107 & 0.9273 & -0.2864 & 0.9190 \\
\hline Read \& write & -0.2508 & 0.2303 & -0.2627 & 0.2314 & $0.4720 * * *$ & 0.1421 & $0.4778 * * *$ & 0.1404 \\
\hline Member of association & -0.0442 & 0.1522 & -0.0454 & 0.1524 & -0.1502 & 0.1744 & -0.1441 & 0.1745 \\
\hline $\begin{array}{l}\text { Main occupation } \\
\text { (Agriculture) }\end{array}$ & -0.1455 & 0.1304 & -0.1438 & 0.1297 & -0.1170 & 0.0985 & -0.1178 & 0.0985 \\
\hline House value (in log) & $0.1205^{* *}$ & 0.0540 & $0.1238 * *$ & 0.0540 & 0.0102 & 0.0430 & 0.0121 & 0.0432 \\
\hline Share of males & $-0.6309 * *$ & 0.2801 & $-0.6286^{* *}$ & 0.2815 & 0.1866 & 0.2633 & 0.1945 & 0.2625 \\
\hline \# observations & 1175 & & 1175 & & 1384 & & 1384 & \\
\hline Log-likelihood & -315.581 & & -315.813 & & -492.388 & & -493.636 & \\
\hline
\end{tabular}

Note: Dependent variable is Risk_Acceptance. The last five variables are excluded instruments. Model 1 corresponds to regressions with Income and Mean village income. Model 2 corresponds to regressions with Poor. Significance levels: $* 10 \%$, $* * 5 \%, * * * 1 \%$. 
Table A15: First-step estimation for Poor and Poor*Income

\begin{tabular}{|c|c|c|c|c|c|c|c|c|}
\hline \multirow[b]{3}{*}{ Variable } & \multicolumn{4}{|c|}{ Vietnam } & \multicolumn{4}{|c|}{ Thailand } \\
\hline & \multicolumn{2}{|c|}{ Poor } & \multicolumn{2}{|c|}{ Poor*Income } & \multicolumn{2}{|c|}{ Poor } & \multicolumn{2}{|c|}{ Poor*Income } \\
\hline & Coef. & Std.Err. & Coef. & Std.Err. & Coef. & Std.Err. & Coef. & Std.Err. \\
\hline $\begin{array}{l}\text { Subjective wealth, } \\
\text { wrt village }\end{array}$ & $-0.4986^{* * * *}$ & 0.0823 & $-0.1978^{*}$ & 0.1126 & $-0.3055^{* * *}$ & 0.0611 & -0.1962 & 0.1522 \\
\hline $\begin{array}{l}\text { Subjective wealth, } \\
\text { wrt country }\end{array}$ & $-0.3351 * * *$ & 0.0884 & -0.2131 & 0.1433 & -0.0499 & 0.0602 & 0.0209 & 0.1434 \\
\hline Drought & $0.2517 *$ & 0.1486 & 0.0295 & 0.1983 & 0.0041 & 0.0850 & 0.2176 & 0.2585 \\
\hline Flooding & 0.0814 & 0.1369 & $0.3926^{*}$ & 0.2077 & -0.0985 & 0.1295 & -0.3889 & 0.2678 \\
\hline Heavy ice rain & 0.0682 & 0.1951 & 0.5617 & 0.4173 & -- & -- & 1.2327 & 1.1252 \\
\hline Storm, landslide & $0.4644 * * *$ & 0.1343 & 0.2292 & 0.2288 & -0.0321 & 0.5194 & -0.8237 & 0.8783 \\
\hline $\begin{array}{l}\text { Pests or livestock } \\
\text { disease }\end{array}$ & 0.0704 & 0.1242 & -0.1097 & 0.1772 & 0.0661 & 0.1756 & -0.0040 & 0.3214 \\
\hline Collapse of business & $0.5721 *$ & 0.3324 & $1.8408 * *$ & 0.8408 & -0.1477 & 0.2844 & -0.5640 & 0.5730 \\
\hline Serious disease & 0.0043 & 0.0804 & 0.0111 & 0.1501 & 0.0789 & 0.0892 & 0.1623 & 0.2138 \\
\hline Average age & -0.0013 & 0.0032 & -0.0029 & 0.0047 & 0.0008 & 0.0036 & -0.0023 & 0.0091 \\
\hline Ethnic minority & -0.1650 & 0.1291 & -0.1510 & 0.2801 & $0.4257 * *$ & 0.1734 & 0.2220 & 0.3809 \\
\hline Access to electricity & $-0.8137 * * *$ & 0.2854 & 0.4923 & 0.6471 & 0.3830 & 0.5334 & -2.0072 & 2.4980 \\
\hline $\begin{array}{l}\text { Access to public } \\
\text { water supply }\end{array}$ & 0.1014 & 0.0905 & 0.4124 & 0.2733 & -0.0079 & 0.0982 & 0.3197 & 0.3977 \\
\hline Access to sanitation & 0.0389 & 0.1228 & $0.7468 * * *$ & 0.2795 & -0.0326 & 0.1399 & -0.1210 & 0.6083 \\
\hline $\begin{array}{l}\text { Access to public } \\
\text { waste disposal }\end{array}$ & 0.2435 & 0.2201 & -0.1155 & 0.6135 & -0.0231 & 0.0911 & -0.1460 & 0.2875 \\
\hline $\begin{array}{l}\text { Access to fixed } \\
\text { phone line }\end{array}$ & $-0.2639 *$ & 0.1562 & -0.4265 & 0.5141 & -0.0509 & 0.0922 & -0.1669 & 0.3216 \\
\hline Access to internet & 1.2586 & 0.8827 & $4.0962 * *$ & 1.6319 & 0.2289 & 0.1662 & 1.4708 & 1.0807 \\
\hline $\begin{array}{l}\text { Travel distance to } \\
\text { district town }\end{array}$ & -0.0020 & 0.0038 & 0.0104 & 0.0082 & $-0.0057 *$ & 0.0032 & $-0.0281 * *$ & 0.0120 \\
\hline Mountain & -0.1067 & 0.0708 & -0.1222 & 0.1746 & $0.4433 * *$ & 0.1930 & -0.2699 & 0.2955 \\
\hline Slope & -0.1379 & 0.1178 & $-0.7022 * * *$ & 0.2460 & -0.1431 & 0.0891 & -0.4023 & 0.3255 \\
\hline Valley & $0.5457 * * *$ & 0.1500 & $1.1081 * * *$ & 0.3491 & 0.0923 & 0.0778 & $-0.6597 * *$ & 0.3201 \\
\hline River & $-0.2469 * *$ & 0.1026 & $-0.4763 *$ & 0.2641 & -0.0428 & 0.0811 & -0.1768 & 0.2780 \\
\hline Lake & $-0.1974 * *$ & 0.0991 & -0.1052 & 0.2543 & -- & -- & -- & -- \\
\hline Coast & 0.1300 & 0.1763 & 0.3319 & 0.3316 & -- & -- & -- & -- \\
\hline Ha Tinh & $-0.2556^{*}$ & 0.1368 & $-1.2527 * * *$ & 0.3181 & -- & -- & -- & -- \\
\hline Thua Thien-Hue & -0.0460 & 0.1428 & $-0.7781 * *$ & 0.3799 & -- & -- & -- & -- \\
\hline Buriram & -- & -- & -- & -- & 0.1297 & 0.0930 & $0.9837 * * *$ & 0.3005 \\
\hline Ubon Ratchathani & -- & -- & -- & -- & -0.0030 & 0.1073 & $0.5818^{*}$ & 0.3401 \\
\hline Constant & $4.3610 * * *$ & 0.5249 & $3.5909 * * *$ & 1.0570 & $2.0584 * * *$ & 0.7003 & $4.8151^{*}$ & 2.6480 \\
\hline Read \& write & -0.2322 & 0.1549 & $-0.4358 * *$ & 0.2040 & 0.0391 & 0.1130 & 0.0386 & 0.2648 \\
\hline $\begin{array}{l}\text { Member of } \\
\text { association }\end{array}$ & 0.1056 & 0.1019 & -0.0218 & 0.1609 & 0.1059 & 0.1559 & 0.4335 & 0.3588 \\
\hline $\begin{array}{l}\text { Main occupation } \\
\text { (Agriculture) }\end{array}$ & -0.0510 & 0.0966 & 0.0491 & 0.1425 & -0.0571 & 0.0774 & -0.0714 & 0.2177 \\
\hline House value (in log) & $-0.1380 * * *$ & 0.0367 & -0.0552 & 0.0541 & $-0.1804 * * *$ & 0.0364 & -0.1034 & 0.0798 \\
\hline Share of males & -0.1321 & 0.2182 & 0.2960 & 0.3669 & 0.0022 & 0.1976 & 0.1024 & 0.4737 \\
\hline \# observations & 1176 & & 1176 & & 1386 & & 1386 & \\
\hline R-squared & & & 0.0721 & & & & 0.0317 & \\
\hline
\end{tabular}

Note: Dependent variable is Poor or Poor*Income. The last five variables are excluded instruments. Model 1 corresponds to regressions with Income and Mean village income. Model 2 corresponds to regressions with Poor. Significance levels: *10\%, $* * 5 \%, * * * 1 \%$. 